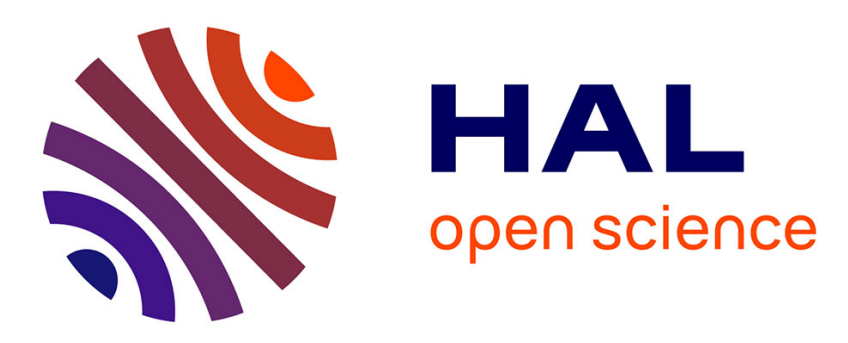

\title{
Assessment of Dietary Exposure of Nitrate and Nitrite in France
}

Céline Menard, Fanny Heraud, Jean-Luc J.L. Volatier, Jean-Charles Leblanc

\section{To cite this version:}

Céline Menard, Fanny Heraud, Jean-Luc J.L. Volatier, Jean-Charles Leblanc. Assessment of Dietary Exposure of Nitrate and Nitrite in France. Food Additives and Contaminants, 2009, 25 (08), pp.971988. 10.1080/02652030801946561. hal-00577381

\section{HAL Id: hal-00577381 https://hal.science/hal-00577381}

Submitted on 17 Mar 2011

HAL is a multi-disciplinary open access archive for the deposit and dissemination of scientific research documents, whether they are published or not. The documents may come from teaching and research institutions in France or abroad, or from public or private research centers.
L'archive ouverte pluridisciplinaire HAL, est destinée au dépôt et à la diffusion de documents scientifiques de niveau recherche, publiés ou non, émanant des établissements d'enseignement et de recherche français ou étrangers, des laboratoires publics ou privés. 


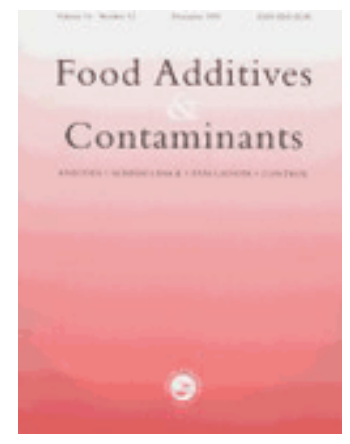

\section{Assessment of Dietary Exposure of Nitrate and Nitrite in France}

\begin{tabular}{|r|l|}
\hline Journal: & Food Additives and Contaminants \\
\hline Manuscript ID: & TFAC-2007-409.R1 \\
\hline Manuscript Type: & Review \\
\hline Author: & 21-Jan-2008 \\
\hline Complete List of Authors: & $\begin{array}{l}\text { MENARD, Céline; French Food Safety Agency, Quantitative Risk } \\
\text { Assessment Team } \\
\text { Heraud, Fanny; French Food Safety Agency, Quantitative Risk } \\
\text { Assessment Team } \\
\text { Volatier, Jean-Luc; French Food Safety Agency, Quantitative Risk } \\
\text { Assessment Team } \\
\text { Leblanc, Jean-Charles; French Food Safety Agency, Quantitative } \\
\text { Risk Assessment Team }\end{array}$ \\
\hline Methods/Techniques: & Exposure assessment \\
\hline Additives/Contaminants: & Nitrate, Nitrite \\
\hline Food Types: & \\
\hline &
\end{tabular}

\section{SCHOLARONE" \\ Manuscripts}


1

2

3

4

5

6

7

8

9

10

11

\section{Assessment of dietary exposure of nitrate and nitrite in France}

Céline MENARD *, Fanny HERAUD, Jean-Luc VOLATIER, Jean-Charles LEBLANC.

Risk Assessment Scientific Support Office, French Food Safety Agency (AFSSA), 27 - 31 avenue du Général Leclerc, 94701 MAISONS-ALFORT Cedex, FRANCE.

* Corresponding author: Céline MENARD

Phone: + 33149771174

Fax: + 33149773892

E-mail: c.menard@afssa.fr

Disclaimer:

The findings and conclusions in this paper are the authors' own and do not necessarily represent the views of the French Food Safety Agency. The authors declare they have no conflict of interests. 


\begin{abstract}
The aim of this study was to assess the dietary exposure of nitrate and nitrite in France. 13657 concentration levels of nitrate and nitrite measured in food, representing 138 and 109 food items respectively and coming from French monitoring programs between 2000-2006, were used. Depending on the non-detected and non-quantified analysis treatment, lower and upper concentration mean estimates were calculated for each food item. These were combined with consumption data of 1474 adults and 1018 children from the French national individual consumption survey (INCA1), conducted in 1999 and based on a seven-day food record diary. $18 \%$ of spinaches, $6 \%$ of salads, $10 \%$ of cheeses, $8 \%$ of meat products and $6 \%$ of industrial meat products exceeded the European nitrate maximum level or maximum residual level. $0.4 \%$ of industrial meat products and $0.2 \%$ of meat products exceeded their European nitrite maximum level or maximum residual level. Nitrate dietary exposure averaged $40 \%$ of the Acceptable Daily Intake (ADI, $3.7 \mathrm{mg} \mathrm{kg}^{-1} \mathrm{bw} \mathrm{day}^{-1}$ ) for adults and $51-54 \%$ of the ADI for children with the major contributors being, for adults and children respectively, vegetables (24 and $27 \% \mathrm{ADI}$ ), potatoes (5 and $11 \% \mathrm{ADI}$ ) and water (5 and $5 \% \mathrm{ADI}$ ). The individual nitrate dietary intake of $1.4 \%$ (Confidence Interval $\left.\left(\mathrm{Cl}_{95 \mathrm{th}}\right)[0.8 ; 2.0]\right)$ to $1.5 \%\left(\mathrm{Cl}_{95 \text { th }}[0.9 ; 2.1]\right)$ of adults and $7.9 \%\left(\mathrm{Cl}_{95 \text { th }}[6.2 ; 9.6]\right)$ to $8.4 \%\left(\mathrm{Cl}_{95 \text { th }}[6.7 ; 10.1]\right)$ of children were higher than the ADI. Nitrite dietary exposure averaged $33-67 \%$ of ADI $\left(0.06 \mathrm{mg} \mathrm{kg}^{-1} \mathrm{bw} \mathrm{day}^{-1}\right)$ for adults and 67 $133 \%$ of $A D I$ for children, with contributions of additive food-vectors at $33 \%$ ADI for adults and $50-67 \%$ ADI for children. The individual nitrite dietary intake of $0.7 \%\left(\mathrm{Cl}_{95 \text { th }}[0.3 ; 1.1]\right)$ to $16.4 \%$ $\left(\mathrm{Cl}_{95 \text { th }}[14.5 ; 18.3]\right)$ of adults and $10.5 \%\left(\mathrm{Cl}_{95 \text { th }}[8.6 ; 12.4]\right)$ to $66.2 \%\left(\mathrm{Cl}_{95 \text { th }}[63.3 ; 69.1]\right)$ of children were higher than the ADI.
\end{abstract}

Keywords: Nitrate, Nitrite, Dietary exposure, foods additives, Acceptable Daily Intake (ADI), exposure assessment. 


\section{Introduction}

Nitrate and nitrite are ions naturally present in the environment. They are used increasingly as food additives to stabilize some meat products and cheeses. But nitrate is mainly used in agriculture as fertilizer. There are many published papers characterizing the presence of nitrate in plant foods such as lettuce and spinach for example or in water. Because of all these sources of nitrate (vegetables, water, meat products) and nitrite (food additives), humans can be exposed to these compounds, although it has been shown that nitrate is also produced endogenously. The human body absorbs the nitrate ingested very easily. However, it is not the nitrate itself that presents a health risk, but its reduction into nitrite (Hartman 1983; FAO/WHO 1998) for which a lot of studies have already shown the effects on human health. The best known health effect of nitrite or nitrate reduced into nitrite is methemoglobinemia in newborn babies, due to the fact that nitrite can prevent hemoglobin from being able to transport oxygen (Comly 1954; FAO/WHO 2002). Moreover, in 1987 Fan et al. showed that high doses of nitrite could have a toxic effect on reproduction (Fan et al. 1987). These observations have since been clearly confirmed (Fan and Steinberg 1996; Manassaram et al. 2006). Nitrite or its degradation compounds have also been shown to be mutagenic. A potential link with the emergence of chromosomal aberrations was demonstrated, as sodium nitrite would lead to an increase in the number of micronucleated polychromatic erythrocytes in vivo in mice (Luca et al. 1987). Finally, nitrite or nitrate reduced to nitrite, could interact with the amide compounds of the stomach to create $\mathrm{N} \_$nitroso coumpounds, which are very carcinogenic for animals in several target organs (Fraser 1985) and even for humans (Broitman et al. 1981). But according to the last conclusions of the Joint FAO/WHO Expert Committee on Food Additives (JECFA) (FAONHO 2003), nitrite does not appear to be carcinogenic and the association between the nitrate ingested and an increased risk of cancer is still debated (Van Grinsven et al. 2006; Ward et al. 2005).

Because of the effects of nitrate and nitrite on health, European standards have been established. Nitrate and nitrite could be present in food items as a natural constituent or due to an intentional addition as additive. So, European standards and this study distinguished between additive foods-vectors contributions, food items for which nitrate and nitrite uses are 
authorized and other food items, food items for which nitrate and nitrite are natural constituents. Besides, French monitoring Program distinguished 'unprepared' from 'pre-prepared' meat products like chicken wings coated with bread-crumbs or ready-to-eat curried chicken, which are food items obtained by specific food industry processes and called industrial prepared meat products in this study. Concerning agricultural uses of nitrate, the European Commission has established Maximal Levels (MLs) for lettuces (2500 - $3500 \mathrm{mg} \mathrm{kg}^{-1}$ for summer salad and 4000 - $4500 \mathrm{mg} \mathrm{kg}^{-1}$ for winter salad) and spinaches $\left(2500 \mathrm{mg} \mathrm{kg}^{-1}\right.$ for summer spinach, $3000 \mathrm{mg} \mathrm{kg}^{-1}$ for winter spinach, $2000 \mathrm{mg} \mathrm{kg}^{-1}$ for frozen spinach) (Commission Regulation (EC) No 1881/2006). Concerning the use of nitrate as an additive, Maximal residual Level (MrLs) have been established for meat products $\left(250 \mathrm{mg} \mathrm{kg}^{-1}\right)$, cheeses and canned foie gras $\left(50 \mathrm{mg} \mathrm{kg}^{-1}\right)$ (Directive 2006/52/EC). Concerning nitrite uses, the European Commission has established several MrLs (Directive 2006/52/EC) for dry cured meat products as bacon (175 mg kg ${ }^{-1}$ ), for dry non-heat-treated meat products $\left(50 \mathrm{mg} \mathrm{kg}^{-1}\right)$ and for others dry cured meat products as dry cured ham $\left(100 \mathrm{mg} \mathrm{kg}^{-1}\right)$. For water, Directive 2003/40/EC also lays down a Maximum Limit for nitrate $\left(50 \mathrm{mg} \mathrm{L}^{-1}\right)$ and nitrite $\left(0.1 \mathrm{mg} \mathrm{L}^{-1}\right)$.

Some studies have already estimated dietary exposure of nitrate and nitrite, which generally does not exceed the ADI in the Netherlands, United Kingdom, Korea or New Zealand (Lee et al. 2006; Thomson et al. 2007; Vaessen and Schothorst 1999; Ysart et al. 1999). The main contributors are often potatoes, green vegetables and other vegetables at $33 \%, 21 \%$ and $15 \%$ respectively of total exposure (Ysart et al. 1999). None of these studies are comparable, however, because some are conducted on the general population and others on adults only. Moreover, some studies are focused on additive food-vectors only (Lee et al. 2006; Verger et al. 1998) and do not take account of the whole diet or the actual levels of nitrate and nitrite found in food items.

Some studies are available in France. A French national duplicate study was first conducted in 1990 (DGS 1992) to estimate nitrate dietary exposure. Meals eaten outside of the home were analyzed and nitrate intake was in average 147.8 and $84.4 \mathrm{mg} /$ day respectively for adults and children. Water contributed to $22 \%$ of the total exposure, some vegetables either consumed in large quantity or highly contaminated contributed to $48 \%$ of the total intake. 
Concerning nitrite exposure in France, it was shown in 1998 that the Theoretical Maximum Daily Intake of nitrite was on average $0.31 \mathrm{mg} \mathrm{kg}^{-1} \mathrm{bw} \mathrm{day}^{-1}$ (Verger et al. 1998). Another study was conducted in 2005 (Bemrah-Aouachria et al. 2007) to integrate nitrite uses in meat products declared by industries. For high consumers, nitrite dietary exposure was between 0.093 and $0.134 \mathrm{mg} \mathrm{kg}^{-1}$ bw day ${ }^{-1}$ for adults and between 0.165 and $0.250 \mathrm{mg} \mathrm{kg}^{-1}$ bw day ${ }^{-1}$ for children. These French studies are either theoretical or based on old data and present contrasting results. A new assessment of dietary exposure of nitrate and nitrite was therefore required for the French population.

This study is the first one to estimate dietary intake of nitrate and nitrite in French adults and children, based on individual consumption data and on concentrations measured in several food items and water. This paper reports the levels of nitrate and nitrite present in several French food items, available on the market between 2000 and 2006, and the level of dietary exposure of nitrate and nitrite with a lower and upper estimate, depending on the non-detected and non-quantified analyses treatment. As recommended by the Joint FAO/WHO Expert Committee on Food Additives (FAO/WHO 2003), all nitrate and nitrite food sources and not only just additive food-vectors were considered in this study. As a result, food groups and food items contributing to dietary exposure were also identified.

\section{Methodology}

The chronic dietary exposure assessment of nitrate and nitrite in France was conducted by comparing the Acceptable Daily Intake ( $\mathrm{ADI}, \mathrm{mg} \mathrm{kg}^{-1}$ bw day ${ }^{-1}$ ) with the dietary exposure calculated as the sum of all concentration levels $\left(\mathrm{mg} \mathrm{kg}^{-1}\right)$, multiplied by the food consumption $\left(\mathrm{g} \mathrm{day}{ }^{-1}\right)$ and divided by the individual body weight (kg bw).

\section{Individual consumption data}

French individual consumption data came from the Enquête Individuelle et Nationale de Consommation Alimentaire (INCA 1) conducted between August 1998 and June 1999. This French study was based on a sample of 1474 healthy adults (aged 15 and over) and 1018 children (between 3 and 14 years old), representative of the French population through 
stratification (region of residence, size of urban area) and use of the quota method (age, gender, household size, individual occupation and socio-professional status) (Volatier 2000). All subjects were asked to complete a seven-day food record diary (consecutive days) as well as other questionnaires on anthropometrical and socio-economical factors. Participants could estimate portion sizes by comparing the amount they were eating with photographs compiled in a manual adapted from the SuViMax picture booklet (Deheeger 1994). Food records were subsequently coded into 895 food items (INCA classification). Adults identified as underreporters according to the ratio of energy intake to estimated basal metabolic rate were excluded, as were those for whom no individual body weight was given. Briefly, according to Schofield (Schofield 1985; Scofield et al. 1985) and Goldberg et al (Goldberg et al. 1991), identification of the individuals' reporting status was based on fundamental principles of energy physiology. Basal metabolic rate (BMR) was first estimated using gender-age-weight specific equations computed by Schofield (1985). Dietary reporting status was then assessed as suggested by Goldberg et al. (1991) by computing a ratio of reported energy intake (EI) to estimated basal metabolic rate (BMR). Tabulated cut-off limits for this El/BMR ratio have been derived by Goldberg et al. (1991) from whole-body calorimeter and doubly labelled water measurements in a wide range of healthy adults. Among our study sample, ratios falling below the 1.1 limit were recognized as being incompatible with long-term maintenance of energy balance and therefore with long-term survival.

Nitrate and nitrite concentration data

Food items. Concentration levels of nitrate and nitrite in foods came from the French national monitoring programs carried out between 2000 and 2006. Monitoring programs are essentially performed on individual composite samples according to sampling guidelines for official control (Commission Regulation (EC) No 1882/2006). These samples are collected on the market and often concern items which are supposed to contribute to dietary exposure. 13657 samples representing 138 commodities for nitrate and 109 commodities for nitrite were analyzed. All concentration levels and mean estimates were compared to the Maximum Level (ML) or the Maximum residual Level (MrL) currently in force for nitrates (Commission Regulation (EC) No 
Water. For tap water, a distribution of nitrate concentrations was obtained from the French database Sise-eaux 2005 (French Ministry of Health - DDASS-SISE-EAUX). To estimate a nitrate concentration mean in tap water, a distribution was recreated using the "Best Fit" function of @Risk, and the estimated mean was obtained. Because there is no nitrite residue in tap water due to the presence of chlorate, two scenarios were conducted: the first considering the nitrite concentration in tap water to be null and the second considering it to be the Maximum Limit (ML) fixed at $0.1 \mathrm{mg} \mathrm{L}^{-1}$, (Directive 2003/40/EC). The nitrate and nitrite concentration means obtained for tap water were also attributed to boiled water (coffee, tea, soup). For water of source origin, data (2732 and 2721 analyses for nitrate and nitrite respectively) from the French database Sise-eaux 2004-2006 (French Ministry of Health - DDASS-SISE-EAUX) was used. For mineral and sparkling mineral water, data (957 and 460 analyses for nitrate and nitrite respectively) from the French database of the AFSSA-LERH-EMN 2004-2007 (National Mineral Water Database of the Hydrology Laboratory of French Food Safety Agency) was used.

\section{Toxicological Reference Values}

ADIs, toxicological reference values established over an entire lifetime, for nitrate and nitrite have been discussed for years. The Joint FAO/WHO Expert Committee on Food Additives (JECFA) (FAONHO 2003) and the Scientific Committee on Food (SCF 1995) of the European Commission conducted several assessments. The nitrate ADI used in this study was $3.7 \mathrm{mg} \mathrm{kg}$ -

${ }^{1}$ bw day ${ }^{-1}$ (SCF 1995, FAO/WHO 2003). For nitrite, because the difference between the 
European (0.06 mg kg ${ }^{-1}$ bw day ${ }^{-1}$ ) (SCF 1995) and international $\left(0.07 \mathrm{mg} \mathrm{kg}^{-1}\right.$ bw day ${ }^{-1}$ ) (FAO/WHO 2003) ADI was very low, the European ADI was used in this study to be consistent with the European MrLs and MLs.

\section{Assessment of dietary exposure}

As recommended by the international guidelines (FAO/WHO 1985; FAOMHO 2000), the use of a residue level mean when calculating dietary exposure is a realistic and appropriate estimation of chronic exposure to be compared to the Acceptable Daily Intake (ADI), a toxicological reference value established over an entire lifetime. Nitrate and nitrite concentration means were therefore calculated for each food item. When less $60 \%$ of the results were censored, i.e. below the LOD or the LOQ, means per food were calculated by setting all non-detected results to the $\mathrm{LOD} / 2$ and all non-quantified results to the $(\mathrm{LOD}+\mathrm{LOQ}) / 2$. When more than $60 \%$ of the results were censored, two mean estimates were calculated, as recommended by the international guidelines (FAOMHO 1995):

- A lower bound one calculated by setting all non-detected results to 0 and all nonquantified results to the LOD,

- An upper bound one calculated by setting all non-detected results to the LOD and all non-quantified results to the LOQ.

So when more $60 \%$ of results were censored, concentration means were obtained by lower and upper bound estimates. When less $60 \%$ of results were censored, concentrations means were obtained by a middle bound estimate.

Contamination and consumption data were linked. Consumption of some specific foods analysed in the nitrite national monitoring program was not declared in the INCA survey. In fact, the INCA survey does not distinguish unprepared meat products from industrial prepared meat products obtained by specific industrial processes (coated with bread-crumbs or curried): industrial prepared meat products based on beef, boar, chicken, duck, hare, pork, poultry, quail, rabbit, turkey, veal or lamb, which are new food items less consumed than the corresponding unprepared meat product. In order to be protective and to take account of the potential contribution of these specific food items in the total intake, these industrial prepared meat 


\section{Results}

Mean of nitrate concentrations

Food items. Nitrate monitoring data concerns 138 foods (Table 1). Only some of these have MLs (Commission Regulation (EC) No 1881/2006), or MrLs. (Directive 2006/52/EC). Concerning salads, $6.2 \%$ of salad concentrations exceeded their ML with 23 winter lettuces (4\%) and 10 other winter salads (2\%) above $4000 \mathrm{mg} \mathrm{kg}^{-1}$ and 16 summer lettuces (3\%), 4 summer green salads (14\%) and 10 other summer salads (2\%) above $2500 \mathrm{mg} \mathrm{kg}^{-1}$. But the mean concentration was $1974 \mathrm{mg} \mathrm{kg}^{-1}$ for lettuces, $1975 \mathrm{mg} \mathrm{kg}^{-1}$ for corn salads and $1783 \mathrm{mg}$ $\mathrm{kg}^{-1}$ for other salads. Concerning spinach, $18 \%$ of spinach concentrations exceeded their ML with 27 winter spinaches (10\%) above $3000 \mathrm{mg} \mathrm{kg}^{-1}$ and 21 summer spinaches (8\%) above $2500 \mathrm{mg} \mathrm{kg}^{-1}$. But the mean concentration in spinach was $1682 \mathrm{mg} \mathrm{kg}^{-1}$. For additive foodvectors, $6.3 \%$ of industrial prepared meat product concentrations exceeded $250 \mathrm{mg} \mathrm{kg}^{-1}$ with 2 turkey-based products (4\%), 1 rabbit-based product (2\%), 25 pork-based products (16\%), 1 
boar-based product $(3 \%)$ and 1 veal-based product $(5 \%)$. But the mean concentration in industrial prepared meat products was below $250 \mathrm{mg} \mathrm{kg}^{-1}$. Concerning unprepared meat products, 311 concentrations (8\%) exceeded $250 \mathrm{mg} \mathrm{kg}^{-1}$ but the mean concentration was below $250 \mathrm{mg} \mathrm{kg}^{-1}$ except in Coppa $\left(\right.$ mean $\left.=394.2 \mathrm{mg} \mathrm{kg}^{-1}\right)$. The mean concentration in canned foie gras exceeded $50 \mathrm{mg} \mathrm{kg}^{-1}$ with $12 \%$ of the analysis above $50 \mathrm{mg} \mathrm{kg}^{-1}$. Concerning cheese, 5 concentrations (10\%) exceeded $50 \mathrm{mg} \mathrm{kg}^{-1}$ but the mean concentration was below $50 \mathrm{mg} \mathrm{kg}^{-1}$, except for processed cheeses and other types of cheese (120 and $60 \mathrm{mg} \mathrm{kg}^{-1}$ respectively).

Water. Mean concentrations of nitrate obtained in water (Table 1), were, for the lower and upper bound respectively, $17.4 \mathrm{mg} \mathrm{L}^{-1}$ for tap water and boiled water, 1.6 and $2.2 \mathrm{mg} \mathrm{L}^{-1}$ for water of source origin, 2.7 and $3.0 \mathrm{mg} \mathrm{L}^{-1}$ for mineral and sparkling mineral water.

Mean nitrite concentrations

Food items. Nitrite monitoring data concerns 109 food items (Table 2). Only some of these are concerned by the food additive uses regulation (Directive 2006/52/EC). 9 meat product concentrations (0.2\%) and 2 industrial prepared meat product concentrations $(0.4 \%)$ exceeded $100 \mathrm{mg} \mathrm{kg}^{-1}$ but mean concentrations in these food items were below $50 \mathrm{mg} \mathrm{kg}^{-1}$, except in Rosette (94 $\left.\mathrm{mg} \mathrm{kg}^{-1}\right)$.

Water. Mean concentrations of nitrite obtained in water (Table 2) were, for the lower and upper bound estimates respectively, 0.0 and $0.1 \mathrm{mg} \mathrm{L}^{-1}$ for tap water and boiled water, 0.0 and 0.03 $\mathrm{mg} \mathrm{L}^{-1}$ for water of source origin and 0.00 and $0.04 \mathrm{mg} \mathrm{L}^{-1}$ for mineral and sparkling mineral water.

\section{Nitrate dietary exposure assessment}

Nitrate dietary exposure levels were almost the same with the lower and the upper bound estimates (Table 3). For adults, dietary exposure was on average $1.5 \mathrm{mg} \mathrm{kg}^{-1}$ bw day ${ }^{-1}(40 \%$ $\mathrm{ADI}$ ) and the 97.5 th percentile was $3.3 \mathrm{mg} \mathrm{kg}^{-1}$ bw day ${ }^{-1}$ (89\% ADI). For children, dietary exposure was on average between 1.9 and $2.0 \mathrm{mg} \mathrm{kg}^{-1}$ bw day ${ }^{-1}$ (51 and 54\% ADI) and the 


\section{Nitrite dietary exposure assessment}

Nitrite dietary exposure levels depended largely on the lower or upper bound estimates chosen (Table 6). For adults, dietary exposure was on average between 0.02 and $0.04 \mathrm{mg} \mathrm{kg}^{-1}$ bw day ${ }^{-1}$ (33 and $67 \%$ of the ADI) and the 97.5 th percentile was between 0.05 and $0.08 \mathrm{mg} \mathrm{kg}^{-1}$ bw day (83 and 133\% ADI). For children, dietary exposure was on average between 0.04 and $0.08 \mathrm{mg}$ $\mathrm{kg}^{-1}$ bw day ${ }^{-1}\left(67\right.$ and $133 \% \mathrm{ADI}$ ) and the 97.5 th percentile was between 0.09 and $0.17 \mathrm{mg} \mathrm{kg}^{-1}$ bw day ${ }^{-1}$ (150 and 283\% ADI). Additive food-vectors contributed on average $0.02 \mathrm{mg} \mathrm{kg}^{-1}$ bw day $^{-1}\left(33 \%\right.$ ADI) for adults and between 0.03 and $0.04 \mathrm{mg} \mathrm{kg}^{-1}$ bw day $^{-1}(50-67 \%$ ADI) for children. The nitrite dietary intake means for adults and children were almost the same as or higher than the ADI $\left(0.06 \mathrm{mg} \mathrm{kg}^{-1}\right.$ bw day $\left.{ }^{-1}\right)$. Table 7 shows that between $0.7 \%\left(\mathrm{Cl}_{95 \mathrm{th}}[0.3 ; 1.1]\right)$ and $16.4 \%\left(\mathrm{Cl}_{95 \mathrm{th}}[14.5 ; 18.3]\right)$ of adults and between $10.5 \%\left(\mathrm{Cl}_{95 \mathrm{th}}[8.6 ; 12.4]\right)$ and $66.2 \%\left(\mathrm{Cl}_{95 \text { th }}\right.$ [63.3; 69.1]) of children have an individual nitrite dietary intake exceeding the ADI. 
Industrial prepared meat products and meat products with intakes at 17 and $17 \%$ of the ADI for adults and 33 and $17 \%$ of the $A D I$ for children (Table 6) were major contributors (i.e. > $5 \%$ of the ADI). Dietary intakes due to vegetables and potatoes exceeded $5 \%$ of the ADI, only for upper bound estimation, with contributions equal to 17 and $33 \%$ of the ADI for vegetables and 17 and $33 \%$ of the ADI for potatoes for adults and children respectively. Major contributors to dietary intake of nitrite, i.e. food contributing to more than $5 \%$ of the ADI were, for adults and children respectively (Table 8), industrial prepared meat products made from chicken , beef ,.

\section{Discussion}

Nitrate dietary exposure

The nitrate dietary exposure level estimated in this study (40\% ADI for adults and $51-54 \%$ ADI for children) is twice as low as the results obtained in the "Diagonale des nitrates" (1.5 versus $2.5 \mathrm{mg} \mathrm{kg}^{-1}$ bw day ${ }^{-1}$ and 2.0 vs. $4.2 \mathrm{mg} \mathrm{kg}^{-1} \mathrm{bw} \mathrm{day}^{-1}$ for adults and children respectively) but is greater than in the Netherlands Duplicate Diet Survey (Vaessen and Schothorst 1999) and in the New Zealand foods and drinking water survey results (Thomson et al. 2007), where nitrate intakes for adults are $30 \%$ and $16 \%$ of the ADI respectively. This could be explained by the fact that the Duplicate Diet Survey and the New Zealand foods and drinking water survey are exposure assessment methods which focus less on contributor items than this study method, which is based on monitoring data more or less targeted on food suspected to represent a risk.

The percentage of individual nitrate exposure exceeding the ADI in this study $(1.4 \%$ $\mathrm{Cl}_{95 \text { th }}[0.8 ; 2.0]$ to $1.5 \mathrm{Cl}_{95 \text { th }}[0.9 ; 2.1]$ of adults and $7.9 \% \mathrm{Cl}_{95 \text { th }}[6.2 ; 9.6]$ to $8.4 \% \mathrm{Cl}_{95 \text { th }}[6.7 ; 10.1]$ of children) is similar to the New Zealand foods and drinking water survey (Thomson et al. 2007). The levels exceeding the ADI are explained by high consumption of the major contributors to total dietary intake, which are vegetables (green salads other than lettuce and corn salad and spinach) and potatoes, consumed in large quantity by the French population. High consumers of vegetables, or vegetarians, have already been identified as subjects more exposed to nitrate (Ministry of Agriculture 1998a; FAO/WHO 2002). These contributors were already identified in France by the "Diagonale des nitrates" (DGS 1992) and other studies 


\section{Nitrite dietary exposure}

The nitrite dietary exposure level estimated in this study (33-67\% ADI for adults and $67-133 \%$ ADI for children) is higher than in the Netherlands Duplicate Diet Survey results (Vaessen and Schothorst 1999), where the majority of studied subjects had an intake of less than $10 \%$ of the ADI, and in the New Zealand foods and drinking water survey ones (Thomson et al. 2007), where nitrite intakes were approximately $13 \%$ of the ADI.

The percentage of individuals with a nitrite exposure exceeding the ADI in this study $\left(0.7 \% \mathrm{Cl}_{95 \text { th }}[0.3 ; 1.1]\right.$ to $16.4 \% \mathrm{Cl}_{95 \text { th }}[14.5 ; 18.3]$ of adults and $10.5 \% \mathrm{Cl}_{95 \mathrm{th}}[8.6 ; 12.4]$ to $66.2 \%$ $\mathrm{Cl}_{95 \mathrm{th}}[63.3 ; 69.1]$ of children) is also higher than the results of the New Zealand study where only $1 \%$ of the exposure scenarios exceeded the ADI, but this New Zealand study included the major contributors only and did not take account of the whole diet. Several points could explain 
these exceedances of the ADI. Firstly, additive food-vectors, for which the use of nitrites as additives is allowed, are the major contributors (33\% ADI for adults and $50-67 \%$ ADI for children). These additive food-vectors contributed on average 1 to 19 times more than the other food items. So, subjects whose nitrite intakes exceed the ADI are high consumers of meat products and industrial meat products. But the additive food-vector contributions, calculated in this study and based on concentrations measured in food, are lower than the results obtained in the first AFSSA study (Bemrah-Aouachria et al. 2007) based on nitrite uses declared by industries, where adult results were 1.2 to 2 times higher (mean at $0.034-0.050 \mathrm{mg} \mathrm{kg}^{-1} \mathrm{bw}$ day $^{-1}$ and P97. $5^{\text {th }}$ at $0.093-0.134 \mathrm{mg} \mathrm{kg}^{-1}$ bw day ${ }^{-1}$ ) and children results were 2 to 3 times higher (mean $0.058-0.088 \mathrm{mg} \mathrm{kg}^{-1}$ bw day ${ }^{-1}$ and P97.5th at $0.165-0.250 \mathrm{mg} \mathrm{kg}^{-1}$ bw day ${ }^{-1}$ ). The higher contributions of additive food-vectors compared to the rest of the diet could be explained by the fact that industrial meat products, items not well identified in the INCA survey and for which no consumption data was available, were assumed to be consumed in the amount equivalent to the consumption data of the corresponding meat, which was consumed in greater quantity. This assumption can overestimate the nitrite dietary exposure.

Moreover, the differences between results of nitrite exposure obtained with the lower and the upper bound estimates are considerable, in particular for vegetables and potatoes. This is due to the fact that analytical limits of the different French laboratories for non-additive foodvectors were higher than for food regulated for the use of nitrites as additives. As a result, although vegetables and potatoes were not quantified, their concentrations, depending on the lower and the upper bound estimates, have an impact on total dietary intake. Indeed vegetables without potatoes and potatoes contributions were 33.4 and $66.6 \%$ ADI for adults and children respectively with the upper bound estimate. But only, $4 \%$ of lettuce, $23 \%$ of others green salads and $8 \%$ of spinaches had detected concentration values. These food items, for which at least one concentration value was detected, contributed to nitrate dietary intake at 4.8 and $5.2 \%$ of the ADI for adults and children respectively with the high scenario. So, except lettuce, others green salads and spinach, the others vegetables and potatoes, for which $100 \%$ of concentrations values are not detected and assumed to be equal to the corresponding LOD, contributed at 28.5 and $61.4 \%$ ADI for adults and children respectively. So, the upper bound 


\section{Study limits}

Contamination data from the national monitoring programs might have been focused on food items which are known to be major contributors to dietary intakes of nitrate and nitrite. This explains why it might not cover the whole diet, because some foods are not taken into account such as cereals products, milk, butter and eggs. Therefore, according to some studies (Kammerer et al. 1992), nitrate concentrations in milk can reach $2 \mathrm{mg} \mathrm{L}^{-1}$, with a milk consumption at $0.4 \mathrm{~L} \mathrm{day}{ }^{-1}$ (with a body weight at $60 \mathrm{~kg}$ for adults and $30 \mathrm{~kg}$ for children), the contribution of milk can reach 0.3 and $0.7 \% \mathrm{ADI}$, for adults and children respectively.

Besides, the food nomenclature correspondences between contamination and consumption data were not perfect due to some foods which were analyzed but not declared to be consumed, the INCA 1 survey being not precise enough for the some foods. Moreover, monitoring programs are essentially based on food items for which nitrate and nitrite uses are allowed. So the number of samples varies considerably from one food item to another and the concentration obtained depends on the food items. This could be because some food items like additive food-vectors for nitrite and vegetables for nitrate are analyzed more frequently than other items in the diet. This important heterogeneity in the analysis number can also have an impact on the results of the dietary exposure levels obtained in this study. It is therefore 
necessary to make the national monitoring program more homogeneous in terms of number of analyses and more representative in terms of food items consumed at the national level.

Another point to mention is the fact that concentrations measured are reported if the concentration is above the LOQ. But if noresult is quantified it does not imply that no nitrate and / or nitrite are present in the food items. This is why two mean estimates are calculated, an upper and a lower one, using analytical limits values. But as it has been shown in this study, there were great differences between analytical limit values. Analytical limits were generally higher for food items for which nitrate or nitrite uses are not allowed. The level of the analytical limits may have a major impact on the exposure estimates that is why upper estimates could be very higher than the lower ones. Improving the sensitivity of these analytical limits, in decreasing analytical limits could refine these upper estimates obtained in this study and decrease the uncertainties on the dietary exposure assessment.

Another point to emphasize is the fact that this study does not take account of the variability of food contamination across regions and seasons. For example, some studies (Ministry of Agriculture 1998a; Vaessen and Schothorst 1999) showed dietary exposure variations according to the season, the nitrate intake mean was $73 \mathrm{mg} \mathrm{day}^{-1}$ in spring vs. $87 \mathrm{mg}$ day $^{-1}$ in autumn and the nitrite intake mean was $0.6 \mathrm{mg} \mathrm{day}^{-1}$ in spring and below $0.2 \mathrm{mg} \mathrm{day}^{-1}$ in autumn. Cooking vegetables has also been shown to reduce nitrate concentrations by up to $75 \%$ (Ministry of Agriculture 1998b). Taking seasons and cooking habits into account would consequently improve this dietary exposure assessment.

Taking account of the endogenous synthesis of nitrate and the proportion of nitrate converted to nitrite in humans, being taken as $5 \%\left(\mathrm{~mol} \mathrm{~mol}{ }^{-1}\right)$ for normally responding individuals and $20 \%$ for those showing a high level of conversion, the endogenous synthesis of nitrite would also improve the nitrate and nitrite exposure assessment. But before this, knowledge of the nitrate and nitrite metabolisms must be improved. It would be foreseen to create a new exposure model of dietary exposure, integrating nitrate with a transformed into nitrite part and the excretion urinal rate, and nitrite with the endogenous synthesis part. Nevertheless, based on present toxicological studies, the nitrate and nitrite effects on human health are still not agreed upon, it is therefore important to keep conducting toxicological studies 
to establish more accurate ADIs and because nitrite causes methemoglobinemia, it would also be appropriate to establish an acute reference dose (FAO/WHO 2002).

Lastly, with nitrate and nitrite intakes exceeding the ADIs, the lists and the levels of the respective MLs and MrLs, essentially lower than the residue levels used in this study, might be reconsidered, as recommended by the Joint FAO/WHO Expert Committee on Food Additives (FAO/WHO 2002) and as it was confirmed by the last intake assessment of the WHO (FAO/WHO 2003).

\section{Conclusion}

This study is the first French estimate of the dietary exposure of nitrate and nitrite based on concentrations analysed in foods (13 657 analyses in foods and 6870 analyses in water). Nitrate dietary exposure is on average lower than the ADI (40\% ADI for adults and $51-54 \%$ ADI for children) but this exposure is not only due to foods for which MLs and MrLs are fixed (lettuce and spinach). Nitrite dietary exposure is on average fairly similar to the ADI (33-67\% ADI for adults and $67-133 \%$ ADI for children) and largely depends on the lower or the upper estimate of the exposure chosen to treat the non-detected and non-quantified analysis results. The major contributors to nitrite dietary exposure are only foods for which nitrite use is authorized. Nitrite dietary exposure, obtained with this approach, is 1 to 3 times lower than the theoretical nitrite dietary exposure previously obtained in France. This is why work on the methodology of dietary exposure assessment must be continued. Analytical limits for nonadditive food-vectors would need to be improved in order to refine the exposure assessment. Consumption data must also be refined to take account of all contaminated food items, even those that are rarely consumed, as has been done in the second French individual consumption survey (INCA2), not yet available. Knowledge of the nitrate and nitrite metabolisms and toxicological effects must also be improved to better characterize the risk of dietary exposure of nitrate and nitrite present in food

\section{Acknowledgements}


Contamination data has been provided by the French Ministry of consumer Affairs « Direction Générale de la concurrence, de la consommation et de la Répression des Fraudes ».

\section{References}

AFSSA-LERH-EMN 2004-2007 (National database of mineral water of the hydrology Laboratory of the French Food Safety Agency).

Bemrah-Aouachria N, Leblanc JC, Volatier JL. 2007. Assessment of dietary exposure to thirteen selected food colors, preservatives, antioxidants, stabilizers, emulsifiers and sweeteners in the French population. In presse.

Broitman SA, Velez H, Vitale JJ. 1981. A possible role of iron deficiency in gastric cancer in Colombia. Advances in Cirrhosis, hyperammonia, and hepatic encephalopathy 135: $155-81$

Comly HH. 1954. Cyanosis in Infants caused by Nitrates in Well Water. Journal of the American Medical Association 129(2): 112-17.

Codex Alimentarius Commission (CAC). 2005. Procedural Manual. CCFAC Policy for Exposure Assessment of Contaminants and Toxins in food or Food Groups, fifteenth edition, pp. 114-117. Available from http://www.fao.org/docrep/009/a0247e/a0247e04.htm

Commission Regulation (EC) No 1881/2006 of 19 December 2006 setting maximum levels for certain contaminants in foodstuffs

Commission Regulation (EC) No 1882/2006 of 19 December 2006 Laying Down Methods of Sampling and Analysis for the Official Control of the Levels of Nitrates in Certain Foodstuffs. 
Fan AM, Steinberg VE. 1996. Health implications of nitrate and nitrite in drinking water: an toxicity. Regulatory Toxicology and Pharmacology 23 (1 Pt 1): 35-43.

Fan AM, Willhite CC, Book SA. 1987. Evaluation of the nitrate drinking water standard with reference to infant methemoglobinemia and potential reproductive toxicity. Regulatory Toxicology and Pharmacology 7(2): 135-48.

Food and Agricultural Organization/World Health Organisation (FAOMHO). 1985. Guidelines for the study of dietary intake of chemicals contaminants. Geneva. Available from: http://www.who.int/foodsafety/publications/chem/Guidelines_chem_contam.pdf 
Food and Agricultural Organization/World Health Organisation (FAOMHO). 1995. GEMS/FoodEURO.Reliable Evaluation of low-Level contamination of Food. Kulmbach. Federal republic Germany, p 8. Available from http://www.who.int/foodsafety/publications/chem/en/lowlevel_may1995.pdf

Food and Agricultural Organization/World Health Organisation (FAOMHO). 1996. WHO Food Additives series 35: Toxicological Evaluation of certain Food additives and contaminants, Forty-fourth meeting of the Joint FAO/WHO. Expert Committee on Food Additives (JECFA). Geneva. Available from http://www.inchem.org/documents/jecfa/jecmono/v35je01.htm

Food and Agricultural Organization/World Health Organisation (FAOMHO). 1998. Guidelines for Drinking-water Quality. Second edition. Geneva. pp.56-67. Available from: http://www.who.int/water_sanitation_health/dwq/2edaddvol2a.pdf

Food and Agricultural Organization/World Health Organisation (FAO/WHO). 2000. Joint FAO/WHO Workshop on Methodology for exposure Assessment of contaminants and Toxins in Food. Geneva. Document WHO/SDE/PHE/FOS/00.5, 20p. Available from: http://www.who.int/foodsafety/publications/chem/en/exposure_june2000.pdf

Food and Agricultural Organization/World Health Organisation (FAOMHO). 2002. Technical Report Series. Evaluation of certain Food Additives. Fifty-ninth meeting of the joint FAO/WHO. Expert Committee on Food Additives (JECFA). Geneva.

Food and Agricultural Organization/World Health Organisation (FAOMHO). 2003. WHO Food Additives series 50: Safety evaluation of certain food additives. Fifty-ninth meeting of the joint FAO/WHO. Expert Committee on Food Additives (JECFA). Geneva. Available from http://www.inchem.org/documents/jecfa/jecmono/v50je01.htm 
Hartman PE. 1983. Review: putative mutagens and carcinogens in foods. I. Nitrate/nitrite ingestion and gastric cancer mortality. Environmental Mutagenesis 5(1): 111-21.

Kammerer M, Pinault L, Pouliquen H. 1992. [Content of nitrate in milk. Relationship with its concentration in the water supply for livestock]. Annales des Recherches Vétérinaires 23(2): 131-8.

Lee $\mathrm{CH}$, Cho YH, Park KH. 2006. Assessment of estimated daily intake of nitrite by average consumption of processed foods in Korea. Food Control 17(12): 950-956.

Luca D, Luca V, Cotor F, Raileanu L. 1987. In vivo and in vitro cytogenetic damage induced by sodium nitrite. Mutation Research 189(3):333-9.

Manassaram DM, Backer LC, Moll DM. 2006. A review of nitrates in drinking water: maternal exposure and adverse reproductive and developmental outcomes. Environmental Health Perspectives 114(3): 320-7.

Ministry of Agriculture, Fisheries and Food. 1998a. Duplicate diet study of vegetables_nitrate analysis. Food Surveillance Information Sheet No.165. (London: ministry of agriculture Fisheries and Food). Available from: http://archive.food.gov.uk/maff/archive/food/infsheet/1998/no165/165dds.htm 
Ministry of Agriculture, Fisheries and Food. 1998b. Nitrate in vegetables. Food Surveillance Information Sheet $N^{\circ} 158$. (London: Ministry of Agriculture, Fisheries and Food).

Available from:

http://archive.food.gov.uk/maff/archive/food/infsheet/1998/no158/158nitra.htm

European Scientific Committee for Food (SCF) report. 1995. Opinions of the Scientific Committee for food on nitrate and nitrite.

Schofield WN. 1985. Predicting basal metabolic rate, new standards and review of previous work. Human Nutrition Clinical Nutrition 39 Suppl 1: 5-41.

Scofield RF, Kosugi K, Schumann WC, Kumaran K, Landau BR. 1985. Quantitative estimation of the pathways followed in the conversion to glycogen of glucose administered to the fasted rat. Journal of Biological Chemistry 260(15): 8777-82.

Sise-eaux database.2005. French Ministry of Health - DDASS-SISE-EAUX.

Thomson BM, Nokes CJ, Cressey PJ. 2007. Intake and risk assessment of nitrate and nitrite from New Zealand foods and drinking water. Food Additives and Contaminants 24(2): 113-21.

Vaessen HA, Schothorst RC. 1999. The oral nitrate and nitrite intake in The Netherlands: evaluation of the results obtained by HPIC analysis of duplicate 24-hour diet samples collected in 1994. Food Additives and Contaminants 16(5): 181-8.

Van Grinsven HJ, Ward MH, Benjamin N, de Kok TM. 2006. Does the evidence about health risks associated with nitrate ingestion warrant an increase of the nitrate standard for drinking water? Environmental Health: A global Access Science Source 5: 26. 
1

2

3

Verger P, Chambolle M, Babayou P, Le Breton S, Volatier JL. 1998. Estimation of the distribution of the maximum theoretical intake for ten additives in France. Food Additives and Contaminants 15(7): 759-66.

Volatier J-L. 2000. Enquête INCA individuelle et nationale sur les consommations alimentaires. 158 pp TEC et DOC ed, Paris, France.

Ward MH, deKok TM, Levallois P, Brender J, Gulis G, Nolan BT, VanDerslice J. 2005. Workgroup report: Drinking-water nitrate and health--recent findings and research needs. Environmental Health Perspectives 113(11): 1607-14.

Ysart G, Miller P, Barrett G, Farrington D, Lawrance P, Harrison N. 1999. Dietary exposures to nitrate in the UK. Food Additives and Contaminants 16(12): 521-32. 


\section{Table 1: Nitrate concentration data}

\begin{tabular}{|c|c|c|c|c|c|c|c|c|c|c|c|}
\hline \multicolumn{12}{|c|}{ Nitrate concentrations in food expressed in $\mathrm{mg} \mathrm{kg}^{-1}$} \\
\hline \multirow[t]{2}{*}{ Food item } & \multirow[t]{2}{*}{$\begin{array}{l}\text { Number of } \\
\text { analyses }\end{array}$} & \multirow[t]{2}{*}{$\begin{array}{l}\% \text { of results } \\
<\text { LOD }\end{array}$} & \multicolumn{2}{|c|}{$\begin{array}{c}\text { Estimate of the average } \\
\text { concentration }\end{array}$} & \multirow{2}{*}{$\begin{array}{c}\text { Maximum } \\
\text { concentration } \\
\text { value }\end{array}$} & \multirow[t]{2}{*}{ Food item } & \multirow[t]{2}{*}{$\begin{array}{l}\text { Number of } \\
\text { analyses }\end{array}$} & \multirow[t]{2}{*}{$\begin{array}{l}\% \text { of results } \\
<\text { LOD }\end{array}$} & \multicolumn{2}{|c|}{$\begin{array}{l}\text { Estimate of the average } \\
\text { concentration }\end{array}$} & \multirow{2}{*}{$\begin{array}{c}\text { Maximum } \\
\text { concentration } \\
\text { value }\end{array}$} \\
\hline & & & \multicolumn{2}{|c|}{ Lower bound Upper bound } & & & & & \multicolumn{2}{|c|}{ Lower bound Upper bound } & \\
\hline Meat products & & & & & & Vegetables other thar & n potatoes & & & & \\
\hline Andouille & 36 & 2.8 & 29.8 & 29.8 & 91 & Artichoke & 1 & 0.0 & 16.0 & 16.0 & 16 \\
\hline Andouillette & 35 & 11.4 & 53.3 & 53.3 & 294 & Asparagus & 32 & 12.5 & 111.6 & 111.6 & 1245 \\
\hline Bacon & 10 & 10.0 & 114.9 & 114.9 & 287 & Avocado & 2 & 0.0 & 1256.0 & 1256.0 & 2483 \\
\hline Bacon bits & 24 & 0.0 & 67.6 & 67.6 & 270 & Beetroot & 3 & 0.0 & 644.3 & 644.3 & 1141 \\
\hline Black pudding (blood sausage) & 41 & 48.8 & 17.2 & 17.2 & 128 & Broccoli & 7 & 14.3 & 442.4 & 442.4 & 1131 \\
\hline Chipolata sausage & 231 & 28.6 & 69.3 & 69.3 & 683 & Brussels sprout & 4 & 25.0 & 24.1 & 24.1 & 78 \\
\hline Chorizo dry sausage & 116 & 4.3 & 164.1 & 164.1 & 685 & Cabbage, green & 16 & 6.3 & 498.3 & 498.3 & 1855 \\
\hline Cocktail sausage & 14 & 14.3 & 101.6 & 101.6 & 510 & Carrot & 185 & 16.2 & 120.7 & 120.7 & 861 \\
\hline Coppa & 5 & 0.0 & 394.2 & 394.2 & 860 & Cauliflower & 29 & 10.3 & 214.2 & 214.2 & 910 \\
\hline Dried sausage & 142 & 10.6 & 85.3 & 85.3 & 642 & Celeriac & 20 & 10.0 & 612.7 & 612.7 & 1861 \\
\hline Dried sausage (sliced) & 438 & 10.1 & 95.7 & 95.7 & 1248 & Celery stalk & 17 & 5.9 & 1240.8 & 1240.8 & 2500 \\
\hline Foie gras, canned & 65 & 13.9 & 196.6 & 196.6 & 11100 & Chicory (Belgian endive) & 35 & 2.9 & 135.1 & 135.1 & 414 \\
\hline Frankfurter sausage & 45 & 4.4 & 67.7 & 67.7 & 464 & Corn salad & 28 & 0.0 & 1975.2 & 1975.2 & 3600 \\
\hline French saveloy & 27 & 22.2 & 69.3 & 69.3 & 342 & Courgette (zucchini) & 43 & 2.3 & 559.3 & 559.3 & 1198 \\
\hline Galantine & 66 & 6.1 & 65.8 & 65.8 & 300 & Cucumber & 33 & 3.0 & 191.6 & 191.6 & 1800 \\
\hline Garlic sausage & 78 & 5.1 & 80.9 & 80.9 & 550 & Eggplant & 23 & 0.0 & 284.4 & 284.4 & 777 \\
\hline Ham, raw & 58 & 19.0 & 240.2 & 240.2 & 3270 & Endive (US chicory) & 35 & 0.0 & 534.2 & 534.2 & 2100 \\
\hline Ham, cooked & 346 & 15.9 & 71.5 & 71.5 & 3000 & Fennel & 9 & 0.0 & 1042.7 & 1042.7 & 3345 \\
\hline Head-cheese (Brawn) & 39 & 7.7 & 133.1 & 133.1 & 866 & Garlic & 4 & 25.0 & 120.5 & 120.5 & 286 \\
\hline Merguez sausage & 382 & 8.4 & 160.2 & 160.2 & 9500 & Green bean & 40 & 2.5 & 449.0 & 449.0 & 922 \\
\hline Montbeliard sausage & 6 & 0.0 & 199.8 & 199.8 & 345 & Leek & 59 & 8.5 & 409.5 & 409.5 & 2960 \\
\hline Mortadella & 19 & 21.1 & 75.0 & 75.0 & 341 & Lettuce & 579 & 1.9 & 1973.9 & 1973.9 & 5600 \\
\hline Morteaux sausage & 22 & 9.1 & 52.5 & 52.5 & 250 & Mushroom & 3 & 33.3 & 116.5 & 116.5 & 341 \\
\hline Pâté & 340 & 16.2 & 62.3 & 62.3 & 2962 & Mushroom, canned & 6 & 16.7 & 24.2 & 24.2 & 78 \\
\hline Pâté in pastry. & 28 & 14.3 & 88.4 & 88.4 & 213 & Onion & 4 & 75.0 & 52.5 & 77.7 & 210 \\
\hline Pâté, duck & 74 & 25.7 & 22.0 & 22.0 & 412 & Other green salads & 403 & 2.7 & 1783.3 & 1783.3 & 6100 \\
\hline Pâté, fish and shellfish & 5 & 20.0 & 27.0 & 27.0 & 42 & Parsley & 16 & 6.3 & 1980.1 & 1980.1 & 4300 \\
\hline Pâté, pork liver & 45 & 17.8 & 91.4 & 91.4 & 773 & Pea & 10 & 60.0 & 21.1 & 21.1 & 79 \\
\hline Pâté, poultry liver & 254 & 14.6 & 65.5 & 65.5 & 2236 & Pepper & 34 & 14.7 & 158.8 & 158.8 & 2870 \\
\hline Rillettes & 102 & 41.2 & 10.5 & 10.5 & 88 & Radish & 19 & 0.0 & 1860.7 & 1860.7 & 5000 \\
\hline Rosette dry sausage & 24 & 25.0 & 101.2 & 101.2 & 296 & Sorrel & 1 & 100.0 & 0.0 & 5.0 & \\
\hline Salami & 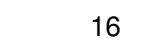 & 25.0 & 94.0 & 94.0 & 458 & Spinach & 266 & 3.4 & 1681.7 & 1681.7 & 8700 \\
\hline
\end{tabular}




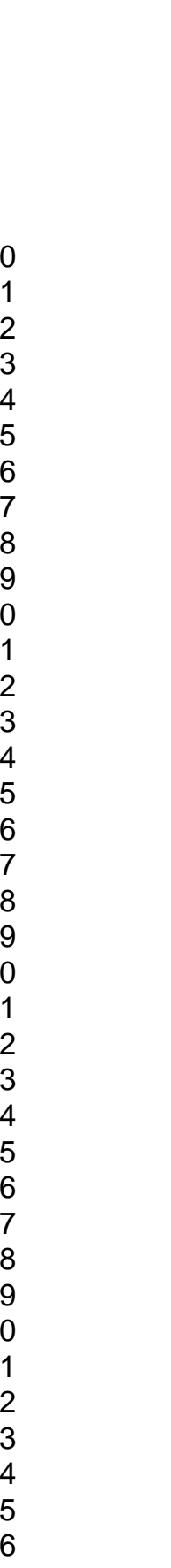

\begin{tabular}{|c|c|c|c|c|}
\hline Sausage meat & 55 & 34.6 & 91.7 & 9 \\
\hline Snack & 15 & 13.3 & 64.9 & \\
\hline Strasbourg sausage & 21 & 9.5 & 87.2 & \\
\hline Toulouse sausage & 379 & 24.0 & 88.7 & \\
\hline Tripes à la mode de Caen & 15 & 0.0 & 16.8 & \\
\hline White pudding (white sausage) & 59 & 37.3 & 12.5 & \\
\hline Other meat products & 17 & 5.9 & 168.3 & \\
\hline \multicolumn{5}{|c|}{ Industrial prepared meat products } \\
\hline Cassoulet, canned & 1 & 0.0 & 33.0 & \\
\hline Confit of duck & 2 & 0.0 & 7.0 & \\
\hline Hare, stewed & 5 & 20.0 & 32.4 & \\
\hline Other processed game & 20 & 30.0 & 16.3 & \\
\hline Pigeon, roasted & 4 & 25.0 & 50.0 & \\
\hline Processed beef & 27 & 11.1 & 37.4 & \\
\hline Processed boar & 37 & 18.9 & 29.4 & \\
\hline Processed chicken & 34 & 26.5 & 21.3 & \\
\hline Processed duck & 48 & 31.3 & 21.2 & \\
\hline Processed hare & 6 & 16.7 & 27.8 & \\
\hline Processed pork & 155 & 12.9 & 105.0 & \\
\hline Processed poultry & 1 & 100.0 & 0.0 & \\
\hline Processed quail & 7 & 28.6 & 27.7 & \\
\hline Processed rabbit & 42 & 11.9 & 53.1 & \\
\hline Processed turkey & 54 & 31.5 & 56.1 & \\
\hline Processed veal & 21 & 57.1 & 41.8 & \\
\hline Processed lamb & 4 & 50.0 & 14.5 & \\
\hline Ravioli with tomato sauce, canned & 1 & 100.0 & 0.0 & \\
\hline Roasted pheasant & 3 & 0.0 & 21.7 & \\
\hline Sauerkraut with meat, canned & 1 & 0.0 & 206.0 & \\
\hline Stuffed escalope of poultry & 3 & 0.0 & 137.7 & \\
\hline Stuffed escalope of veal & 2 & 100.0 & 0.0 & \\
\hline \multicolumn{5}{|l|}{ Offal } \\
\hline Liver, poultry & 7 & 28.6 & 8.9 & \\
\hline Tongue, beef & 3 & 33.3 & 12.0 & \\
\hline Rapeseed oil & 1 & 0.0 & 55.0 & \\
\hline \multicolumn{4}{|l|}{ Cheese } & \\
\hline Bonbel-Babybel $\circledast$ type cheese & 3 & 100.0 & 0.0 & \\
\hline Edam cheese & 4 & 0.0 & 13.0 & \\
\hline Emmental cheese & 1 & 100.0 & 0.0 & \\
\hline Ewe's cheese & 2 & 0.0 & 2.5 & \\
\hline
\end{tabular}

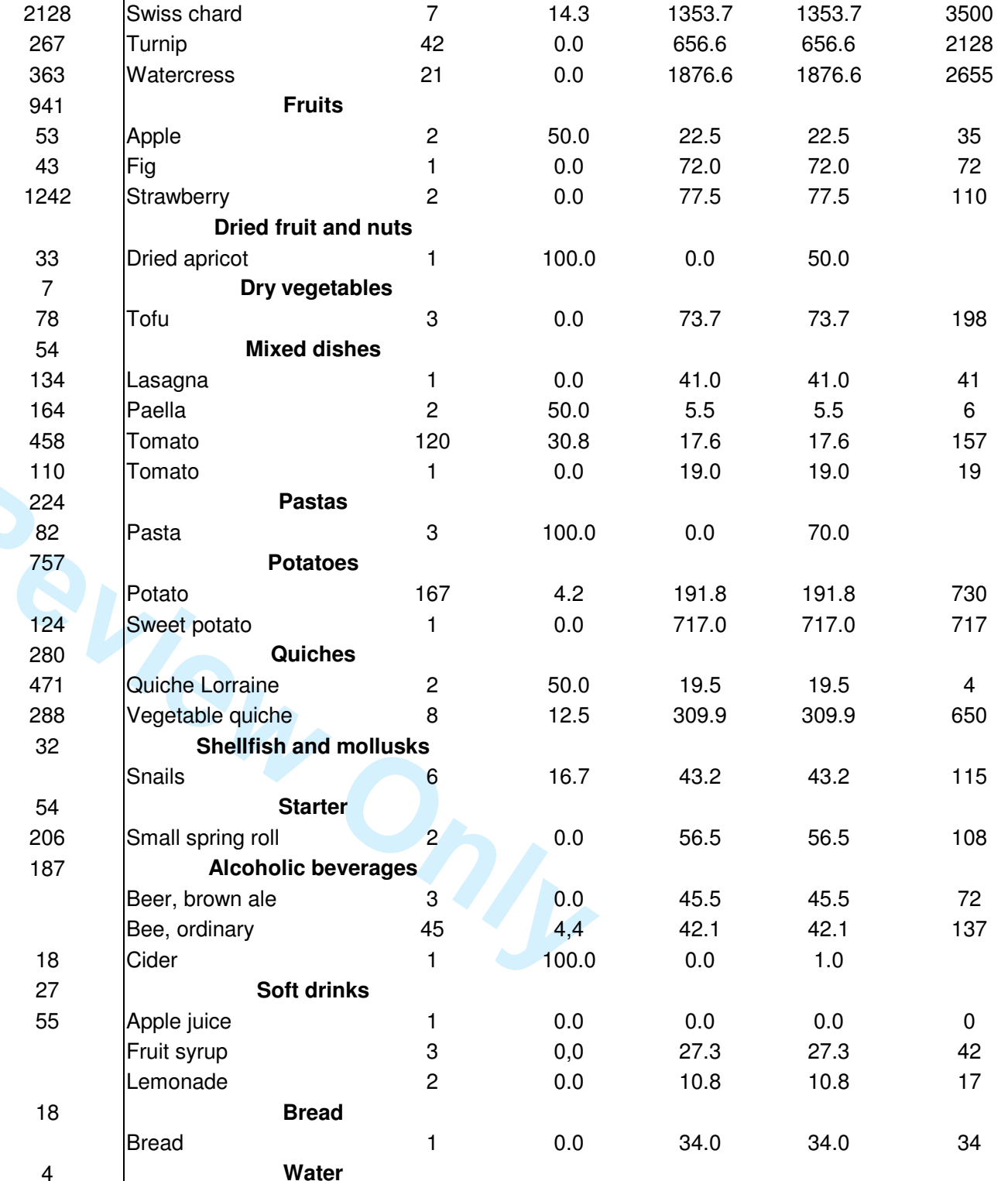




\begin{tabular}{|c|c|c|c|c|c|c|c|c|c|c|c|}
\hline Gouda cheese & 2 & 0.0 & 21.5 & 21.5 & 33 & Mineral water & 957 & 32.5 & 2.7 & 3.0 & l \\
\hline Maasdam $\AA$ type cheese & 1 & 0.0 & 12.0 & 12.0 & 12 & Sparkling mineral water & & & 2.7 & 3.0 & l \\
\hline Mimolette $\AA$ type cheese & 22 & 40.9 & 14.9 & 14.9 & 55 & Tap water & l & l & 17.4 & 17.4 & l \\
\hline Other cheeses & 5 & 20.0 & 120.0 & 120.0 & 225 & Water of source origin & 2732 & 55,6 & 1.6 & 2.2 & l \\
\hline Port Salut $\AA^{\circledR}$ type cheeses & 2 & 100.0 & 0.0 & 10.0 & & Boiled Water & & & & & \\
\hline Processed cheese & 5 & 0.0 & 60.0 & 60.0 & 280 & Coffee & l & / & 17.4 & 17.4 & I \\
\hline Saint-Paulin $\AA^{\circledR}$ type cheese & 1 & 100.0 & 0.0 & 10.0 & & Tea & 1 & I & 17.4 & 17.4 & I \\
\hline Appetizer cheese & 1 & 0.0 & 12.0 & 12.0 & 12 & Soup & l & / & 17.4 & 17.4 & 1 \\
\hline
\end{tabular}

Wen less $60 \%$ of results < LOD, upper and lower bound estimates of concentration means correspond to middle bound estimates. Censored results correspond to analyses for which contamination levels were non-detected or non-quantified 
Table 2 : Nitrite concentration data

\begin{tabular}{|c|c|c|c|c|c|c|c|c|c|c|c|}
\hline \multicolumn{12}{|c|}{ Nitrite concentrations in food expressed in $\mathrm{mg} \mathrm{kg}^{-1-}$} \\
\hline \multirow[t]{2}{*}{ Food item } & \multirow[t]{2}{*}{$\begin{array}{l}\text { Number of } \\
\text { analyses }\end{array}$} & \multirow{2}{*}{$\begin{array}{l}\% \text { of results } \\
<\text { LOD }\end{array}$} & \multicolumn{2}{|c|}{$\begin{array}{c}\text { Estimate of the average } \\
\text { concentrations }\end{array}$} & \multirow{2}{*}{$\begin{array}{l}\text { Maximum } \\
\text { concentration } \\
\text { value }\end{array}$} & \multirow[t]{2}{*}{ Commodities } & \multirow[t]{2}{*}{$\begin{array}{l}\text { Number of } \\
\text { analyses }\end{array}$} & \multirow[t]{2}{*}{$\begin{array}{l}\% \text { of results } \\
<L O D\end{array}$} & \multicolumn{2}{|c|}{$\begin{array}{l}\text { Estimate of the average } \\
\text { concentrations }\end{array}$} & \multirow{2}{*}{$\begin{array}{c}\text { Maximum } \\
\text { concentration } \\
\text { value }\end{array}$} \\
\hline & & & Lower boun & pper bound & & & & & $\begin{array}{l}\text { Lower } \\
\text { bound }\end{array}$ & $\begin{array}{l}\text { Upper } \\
\text { bound }\end{array}$ & \\
\hline \multicolumn{2}{|l|}{ Meat products } & & & & & \multicolumn{2}{|l|}{ Cheese } & & & & \\
\hline Andouille & 39 & 5.1 & 13.54 & 13.54 & 76 & Bonbel-Babybel $\AA$ type cheese & 3 & 66.7 & 0.33 & 1.00 & 1 \\
\hline Andouillette & 48 & 22.9 & 11.68 & 11.68 & 67 & Edam cheese & 4 & 75.0 & 0.75 & 1.50 & 3 \\
\hline Bacon & 19 & 26.3 & 10.09 & 10.09 & 45 & Ewe's cheese & 2 & 100.0 & 0.00 & 0.10 & \\
\hline Bacon bits & 40 & 5.0 & 16.65 & 16.65 & 59 & Gouda cheese & 1 & 100.0 & 0.00 & 1.00 & \\
\hline Black pudding (blood sausage) & 49 & 79.6 & 1.04 & 2.49 & 19 & Maasdam $\AA$ type cheese & 1 & 100.0 & 0.00 & 1.00 & \\
\hline Chipolata sausage & 298 & 78.9 & 2.05 & 3.00 & 71 & Mimolette $\AA$ type cheese & 17 & 94.1 & 0.06 & 0.84 & 1 \\
\hline Chorizo dry sausage & 139 & 35.3 & 3.30 & 3.30 & 16 & Other cheeses & 6 & 100.0 & 0.00 & 1.00 & \\
\hline Cocktail sausage & 16 & 31.3 & 9.41 & 9.41 & 26 & Port Salut $\circledast$ type cheese & 2 & 50.0 & 1.25 & 1.25 & 2 \\
\hline Coppa & 6 & 0.0 & 25.50 & 25.50 & 51 & Processed cheese & 5 & 60.0 & 0.70 & 0.70 & 1 \\
\hline Dried sausage & 176 & 22.7 & 8.54 & 8.54 & 75 & Saint-Paulin $\AA$ type cheese & 1 & 100.0 & 0.00 & 1.00 & \\
\hline Dried sausage (slices) & 567 & 17.1 & 11.60 & 11.60 & 79 & Small cheese for aperitif & 1 & 100.0 & 0.00 & 1.00 & \\
\hline Foie gras, canned & 75 & 26.7 & 4.36 & 4.36 & 12 & \multicolumn{2}{|c|}{ Vegetables other than potatoes } & & & & \\
\hline Frankfurter sausage & 44 & 2.3 & 30.00 & 30.00 & 71 & Artichoke & 1 & 100.0 & 0.00 & 2.00 & \\
\hline French saveloy & 45 & 2.2 & 34.01 & 34.01 & 77 & Avocado & 1 & 100.0 & 0.00 & 20.00 & \\
\hline Galantine & 79 & 29.1 & 10.20 & 10.20 & 54 & Broccoli & 2 & 100.0 & 0.00 & 2.00 & \\
\hline Garlic sausage & 107 & 2.8 & 29.67 & 29.67 & 76 & Brussels sprout & 1 & 100.0 & 0.00 & 2.00 & \\
\hline Ham, raw & 73 & 32.9 & 8.77 & 8.77 & 118 & Cabbage, green & 7 & 100.0 & 0.00 & 18.57 & \\
\hline Ham, cooked & 470 & 12.1 & 11.22 & 11.22 & 190 & Carrot & 84 & 100.0 & 0.00 & 4.15 & \\
\hline Head-cheese (Brawn) & 51 & 19.6 & 12.29 & 12.29 & 71 & Cauliflower & 4 & 100.0 & 0.00 & 2.00 & \\
\hline Merguez sausage & 469 & 72.3 & 3.04 & 3.99 & 220 & Celeriac & 3 & 100.0 & 0.00 & 2.00 & \\
\hline Montbeliard sausage & 6 & 0.0 & 19.00 & 19.00 & 42 & Celery stalk & 7 & 100.0 & 0.00 & 2.00 & \\
\hline Mortadella & 25 & 4.0 & 17.02 & 17.02 & 54 & Chicory (Belgian endive) & 3 & 100.0 & 0.00 & 2.00 & \\
\hline Morteaux sausage & 23 & 4.4 & 5.89 & 5.89 & 40 & Corn salad & 23 & 100.0 & 0.00 & 2.00 & \\
\hline Pâté & 428 & 53.7 & 3.44 & 3.44 & 36 & Courgette (zucchini) & 3 & 100.0 & 0.00 & 2.00 & \\
\hline Pâté in pastry & 36 & 19.4 & 9.93 & 9.93 & 34 & Cucumber & 4 & 100.0 & 0.00 & 2.00 & \\
\hline Pâté, duck & 101 & 64.4 & 2.70 & 3.43 & 43 & Endive (US chicory) & 10 & 100.0 & 0.00 & 7.40 & \\
\hline Pâté, fish and shellfish & 11 & 90.9 & 0.09 & 1.36 & 1 & Garlic & 1 & 100.0 & 0.00 & 2.00 & \\
\hline Pâté, pork liver & 67 & 58.2 & 7.65 & 7.65 & 352 & Green bean & 2 & 100.0 & 0.00 & 15.00 & \\
\hline Pâté, poultry liver & 335 & 49.0 & 6.01 & 6.01 & 500 & Leek & 15 & 100.0 & 0.00 & 2.53 & \\
\hline Rillettes & 136 & 74.3 & 1.65 & 2.60 & 42 & Lettuce & 259 & 99.6 & 0.10 & 6.25 & 25 \\
\hline
\end{tabular}


Rosette dry sausage

Salami

Sausage meat

Snack

Strasbourg sausage

Toulouse sausage

Tripes à la mode de Caen

Vegetable terrines and mousses

White pudding (white sausage)

Other meat products

$$
\text { Offal }
$$

Liver, poultry

Tongue, beef

Industrial prepared meat products

Hare, stewed

Other processed games

Other processed meat products

Pigeon, roasted

Processed beef

Processed boar

Processed chicken

Processed duck

Processed hare

Processed lamb

Processed pork

Processed quail

Processed rabbit

Processed turkey

Processed veal

Roasted pheasant

$\begin{array}{cccc}28 & 28.6 & 93.79 & 93.79 \\ 22 & 36.4 & 4.36 & 4.36 \\ 66 & 75.8 & 3.35 & 4.53 \\ 20 & 15.0 & 18.23 & 18.23 \\ 33 & 9.1 & 23.53 & 23.53 \\ 459 & 74.1 & 2.45 & 3.49 \\ 18 & 77.8 & 1.17 & 1.94 \\ 1 & 0.0 & 4.00 & 4.00 \\ 72 & 88.9 & 0.15 & 1.10 \\ 23 & 17.4 & 18.00 & 18.00 \\ & & & \\ 12 & 75.0 & 1.08 & 1.83 \\ 3 & 0.0 & 8.00 & 8.00 \\ \text { ducts } & & & \\ 5 & 60.0 & 3.30 & 3.30 \\ 28 & 67.9 & 3.86 & 4.68 \\ 4 & 75.0 & 1.75 & 2.50 \\ 4 & 75.0 & 2.25 & 4.00 \\ 18 & 61.1 & 7.33 & 8.17 \\ 44 & 77.3 & 2.39 & 3.25 \\ 41 & 29.3 & 15.12 & 15.12 \\ 45 & 60.0 & 3.77 & 3.77 \\ 6 & 33.3 & 7.50 & 7.50 \\ 5 & 20.0 & 5.70 & 5.70 \\ 171 & 32.8 & 9.75 & 9.75 \\ 7 & 85.7 & 0.29 & 1.71 \\ 63 & 46.0 & 6.15 & 6.15 \\ 80 & 40.0 & 17.66 & 17.66 \\ 27 & 81.5 & 2.22 & 3.04 \\ 4 & 75.0 & 5.50 & 6.25\end{array}$

883
36
77
164
68
76
14
4
3
78

6
11

11
27
7
9
46
43
43
32
20
15
155
2
44
154
23
22

\begin{tabular}{|l} 
Onion \\
Other green salads \\
Parsley \\
Pea \\
Pepper \\
Radish \\
Sorrel \\
Spinach \\
Swiss chard \\
Turnip \\
Watercress
\end{tabular}

Watercress

\section{Potatoes}

Potato Oils

Rapeseed oil

Pastas

Pasta Quiches

2
128
7

Wen less $60 \%$ of results < LOD, upper and lower bound estimates of concentration means correspond to middle bound estimates.

Censored results correspond to analyses for which contamination levels were non-detected or non-quantified 
Table 3: Consumption and dietary exposure of nitrate

\begin{tabular}{|c|c|c|c|c|c|c|c|c|c|c|}
\hline \multicolumn{11}{|c|}{ Food groups consumption $\left(\mathrm{g} \mathrm{day}^{-1}\right)$ and dietary exposure of nitrate $\left(\mathrm{mg} \mathrm{kg}^{-1} \mathrm{bw}\right.$ day $\left.^{-1}\right)$} \\
\hline \multirow[t]{2}{*}{ Food Groups } & \multirow{2}{*}{$\begin{array}{l}\text { Number of } \\
\text { consumers }\end{array}$} & \multirow{2}{*}{$\begin{array}{c}\text { Consumption } \\
\text { Mean }\end{array}$} & \multicolumn{4}{|c|}{ Lower bound estimate } & \multicolumn{4}{|c|}{ Upper bound estimate } \\
\hline & & & Mean & $\begin{array}{c}\text { Mean in } \\
\% \text { ADI }\end{array}$ & P 97.5 & $\begin{array}{c}\text { P } 97.5 \% \\
\text { ADI }\end{array}$ & Mean & $\begin{array}{c}\text { Mean in } \\
\% \text { ADI }\end{array}$ & P 97.5 & $\begin{array}{c}\text { P97.5 \% } \\
\text { ADI }\end{array}$ \\
\hline \multicolumn{11}{|l|}{ For Adults $>15$ years $(n=1474)$} \\
\hline Alcoholic beverages & 338 & 31.5 & $<0.05$ & $<0.05$ & 0.2 & 5.4 & $<0.05$ & $<0.05$ & 0.2 & 5.4 \\
\hline Bread & 1404 & 117.7 & 0.1 & 2.7 & 0.2 & 5.4 & 0.1 & 2.7 & 0.2 & 5.4 \\
\hline Cheese & 494 & 3.7 & $<0.05$ & $<0.05$ & $<0.05$ & $<0.05$ & $<0.05$ & $<0.05$ & $<0.05$ & $<0.05$ \\
\hline Dried fruit and nuts & 6 & 0,1 & $<0.05$ & $<0.05$ & $<0.05$ & $<0.05$ & $<0.05$ & $<0.05$ & $<0.05$ & $<0.05$ \\
\hline Dry vegetables & 1 & $<0.05$ & $<0.05$ & $<0.05$ & $<0.05$ & $<0.05$ & $<0.05$ & $<0.05$ & $<0.05$ & $<0.05$ \\
\hline Fruit & 813 & 47.3 & $<0.05$ & $<0.05$ & 0.1 & 2.7 & $<0.05$ & $<0.05$ & 0.1 & 2.7 \\
\hline Industrial prepared meat products & 1450 & 112.0 & 0.1 & 2.7 & 0.3 & 8.1 & 0.1 & 2.7 & 0.3 & 8.1 \\
\hline Meat products & 1362 & 37.0 & 0.1 & 2.7 & 0.2 & 5.4 & 0.1 & 2.7 & 0.2 & 5.4 \\
\hline Mixed dishes & 1373 & 11.5 & $<0.05$ & $<0.05$ & $<0.05$ & $<0.05$ & $<0.05$ & $<0.05$ & $<0.05$ & $<0.05$ \\
\hline Soft drinks & 216 & 7.8 & $<0.05$ & $<0.05$ & $<0.05$ & $<0.05$ & $<0.05$ & $<0.05$ & $<0.05$ & $<0.05$ \\
\hline Offal & 104 & 1.1 & $<0.05$ & $<0.05$ & $<0.05$ & $<0.05$ & $<0.05$ & $<0.05$ & $<0.05$ & $<0.05$ \\
\hline Oil & 1 & $<0.05$ & $<0.05$ & $<0.05$ & $<0.05$ & $<0.05$ & $<0.05$ & $<0.05$ & $<0.05$ & $<0.05$ \\
\hline Pasta & 407 & 35.8 & $<0.05$ & $<0.05$ & $<0.05$ & $<0.05$ & $<0.05$ & $<0.05$ & 0.2 & 5.4 \\
\hline Potatoes & 1132 & 62.6 & 0.2 & 5.4 & 0.5 & 13.5 & 0.2 & 5.4 & 0.5 & 13.5 \\
\hline Quiches & 287 & 8.0 & $<0.05$ & $<0.05$ & 0.1 & 2.7 & $<0.05$ & $<0.05$ & 0.1 & 2.7 \\
\hline Shellfish and mollusks & 17 & 0.1 & $<0.05$ & $<0.05$ & $<0.05$ & $<0.05$ & $<0.05$ & $<0.05$ & $<0.05$ & $<0.05$ \\
\hline Starters & 88 & 1.7 & $<0.05$ & $<0.05$ & $<0.05$ & $<0.05$ & $<0.05$ & $<0.05$ & $<0.05$ & $<0.05$ \\
\hline Vegetables excluding potatoes & 1437 & 110.8 & 0.9 & 24.3 & 2.6 & 70.3 & 0.9 & 24.3 & 2.6 & 70.3 \\
\hline Water & 1389 & 556.9 & 0.1 & 2.7 & 0.3 & 8.1 & 0.1 & 2.7 & 0.3 & 8.1 \\
\hline Boiled Water & 1363 & 324.6 & 0.1 & 2.7 & 0.3 & 8.1 & 0.1 & 2.7 & 0.3 & 8.1 \\
\hline Total & & 1470.1 & 1.5 & 40.5 & 3.3 & 89.2 & 1.5 & 40.5 & 3.3 & 89.2 \\
\hline \multicolumn{11}{|c|}{ Children between 3 and 14 years of age $(n=1018)$} \\
\hline Alcoholic beverages & 20 & 0.5 & $<0.05$ & $<0.05$ & $<0.05$ & $<0.05$ & $<0.05$ & $<0.05$ & $<0.05$ & $<0.05$ \\
\hline Bread & 921 & 58.9 & 0.1 & 2.7 & 0.3 & 8.1 & 0.1 & 2.7 & 0.3 & 8.1 \\
\hline Cheese & 398 & 3.4 & $<0.05$ & $<0.05$ & 0.1 & 2.7 & $<0.05$ & $<0.05$ & 0.1 & 2.7 \\
\hline Dried fruit and nuts & 1 & 0 & $<0.05$ & $<0.05$ & $<0.05$ & $<0.05$ & $<0.05$ & $<0.05$ & $<0.05$ & $<0.05$ \\
\hline Dry vegetables & & $<0.05$ & $<0.05$ & $<0.05$ & $<0.05$ & $<0.05$ & $<0.05$ & $<0.05$ & $<0.05$ & $<0.05$ \\
\hline Fruits & 494 & 22.3 & $<0.05$ & $<0.05$ & 0.2 & 5.4 & $<0.05$ & $<0.05$ & 0.2 & 5.4 \\
\hline
\end{tabular}




\begin{tabular}{|c|c|c|c|c|c|c|c|c|c|c|}
\hline Industrial prepared meat products & 1011 & 90.9 & 0.1 & 2.7 & 0.5 & 13.5 & 0.2 & 5.4 & 0.5 & 13.5 \\
\hline Meat products & 932 & 27.2 & 0.1 & 2.7 & 0.3 & 8.1 & 0.1 & 2.7 & 0.3 & 8.1 \\
\hline Mixed dishes & 989 & 9.3 & $<0.05$ & $<0.05$ & 0.1 & 2.7 & $<0.05$ & $<0.05$ & 0.1 & 2.7 \\
\hline Soft drinks & 437 & 22.7 & $<0.05$ & $<0.05$ & 0.1 & 2.7 & $<0.05$ & $<0.05$ & 0.1 & 2.7 \\
\hline Offal & 44 & 0.5 & $<0.05$ & $<0.05$ & $<0.05$ & $<0.05$ & $<0.05$ & $<0.05$ & $<0.05$ & $<0.05$ \\
\hline Oil & & $<0.05$ & $<0.05$ & $<0.05$ & $<0.05$ & $<0.05$ & $<0.05$ & $<0.05$ & $<0.05$ & $<0.05$ \\
\hline Pasta & 246 & 36.7 & $<0.05$ & $<0.05$ & $<0.05$ & $<0.05$ & 0.1 & 2.7 & 0.3 & 8.1 \\
\hline Potatoes & 881 & 59.1 & 0.4 & 10.8 & 1.2 & 32.4 & 0.4 & 10.8 & 1.2 & 32.4 \\
\hline Quiches & 216 & 4.8 & $<0.05$ & $<0.05$ & 0.2 & 5.4 & $<0.05$ & $<0.05$ & 0.2 & 5.4 \\
\hline Shellfish and mollusks & 10 & 0.1 & $<0.05$ & $<0.05$ & $<0.05$ & $<0.05$ & $<0.05$ & $<0.05$ & $<0.05$ & $<0.05$ \\
\hline Starters & 50 & 1.0 & $<0.05$ & $<0.05$ & $<0.05$ & $<0.05$ & $<0.05$ & $<0.05$ & $<0.05$ & $<0.05$ \\
\hline Vegetables without potatoes & 983 & 67.1 & 1.0 & 27.0 & 3.7 & 100.0 & 1.0 & 27.0 & 3.7 & 100.0 \\
\hline Water & 990 & 477.7 & 0.2 & 5.4 & 0.7 & 18.9 & 0.2 & 5.4 & 0.7 & 18.9 \\
\hline Boiled Water & 577 & 45.2 & $<0.05$ & $<0.05$ & 0.1 & 2.7 & $<0.05$ & $<0.05$ & 0.1 & 2.7 \\
\hline Total & 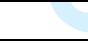 & 927.3 & 1.9 & 51.4 & 4.8 & 129.7 & 2.0 & 54.1 & 4.9 & 132.4 \\
\hline
\end{tabular}


Table 4 : Individual exposure of nitrate exceeding the ADI

\section{Individual exposure exceeding the ADI}

\begin{tabular}{|c|c|c|c|c|}
\hline & \multicolumn{2}{|c|}{ Low estimation } & \multicolumn{2}{|c|}{ High estimation } \\
\hline & $\begin{array}{l}\% \text { of people } \\
\text { over the ADI }\end{array}$ & {$[95 \% \mathrm{Cl}]$} & $\begin{array}{l}\text { \% of people } \\
\text { over the ADI }\end{array}$ & {$[95 \% \mathrm{Cl}]$} \\
\hline Adults $>15$ years $(n=1474)$ & 1.4 & {$[0.8 ; 2.0]$} & 1.5 & {$[0.9 ; 2.1]$} \\
\hline Children between 3 and 14 years of age $(n=1018)$ & 7.9 & {$[6.2 ; 9.6]$} & 8.4 & {$[6.7 ; 10.1]$} \\
\hline
\end{tabular}


Table 5: Major food contributors to nitrate exposure

\begin{tabular}{|c|c|c|c|c|c|c|c|c|c|c|}
\hline \multicolumn{11}{|c|}{ Food consumption $\left(\mathrm{g} \mathrm{day}^{-1}\right)$ and dietary exposure of nitrate $\left(\mathrm{mg} \mathrm{kg}^{-1}\right.$ bw day $\left.{ }^{-1}\right)$} \\
\hline & \multicolumn{2}{|c|}{ Consumption } & \multicolumn{4}{|c|}{ Lower bound estimate } & \multicolumn{4}{|c|}{ Upper bound estimate } \\
\hline & $\begin{array}{c}\text { Adults }>15 \\
\text { years }\end{array}$ & $\begin{array}{c}\text { Children } \\
\text { between } 3 \\
\text { and } 14 \text { years } \\
\text { of age }\end{array}$ & \multicolumn{2}{|c|}{ Adults $>15$ years } & \multicolumn{2}{|c|}{$\begin{array}{l}\text { Children between } 3 \\
\text { and } 14 \text { years of age }\end{array}$} & \multicolumn{2}{|c|}{ Adults $>15$ years } & \multicolumn{2}{|c|}{$\begin{array}{l}\text { Children between } 3 \\
\text { and } 14 \text { years of age }\end{array}$} \\
\hline & Mean & Mean & Mean & $\begin{array}{l}\text { Mean \% } \\
\text { ADI }\end{array}$ & Mean & $\begin{array}{l}\text { Mean \% } \\
\text { ADI }\end{array}$ & Mean & $\begin{array}{l}\text { Mean \% } \\
\text { ADI }\end{array}$ & Mean & $\begin{array}{c}\text { Mean \% } \\
\text { ADI }\end{array}$ \\
\hline Vegetables & + & & & & & & & & & \\
\hline Artichoke & 4.3 & 2.0 & $<0.05$ & $<0.05$ & $<0.05$ & $<0.05$ & $<0.05$ & $<0.05$ & $<0.05$ & $<0.05$ \\
\hline Asparagus & 2.2 & 0.5 & $<0.05$ & $<0.05$ & $<0.05$ & $<0.05$ & $<0.05$ & $<0.05$ & $<0.05$ & $<0.05$ \\
\hline Avocado & 2.8 & 1.6 & 0.1 & 2.7 & 0.1 & 2.7 & 0.1 & 2.7 & 0.1 & 2.7 \\
\hline Beetroot & 2.4 & 1.8 & $<0.05$ & $<0.05$ & $<0.05$ & $<0.05$ & $<0.05$ & $<0.05$ & $<0.05$ & $<0.05$ \\
\hline Broccoli & 1.9 & 1.3 & $<0.05$ & $<0.05$ & $<0.05$ & $<0.05$ & $<0.05$ & $<0.05$ & $<0.05$ & $<0.05$ \\
\hline Brussels sprout & 1.0 & 0.6 & $<0.05$ & $<0.05$ & $<0.05$ & $<0.05$ & $<0.05$ & $<0.05$ & $<0.05$ & $<0.05$ \\
\hline Carrot & 9.8 & 8.5 & $<0.05$ & $<0.05$ & $<0.05$ & $<0.05$ & $<0.05$ & $<0.05$ & $<0.05$ & $<0.05$ \\
\hline Cabbage, green & 0.3 & 0.1 & $<0.05$ & $<0.05$ & $<0.05$ & $<0.05$ & $<0.05$ & $<0.05$ & $<0.05$ & $<0.05$ \\
\hline Cauliflower & 5.5 & 3.6 & $<0.05$ & $<0.05$ & $<0.05$ & $<0.05$ & $<0.05$ & $<0.05$ & $<0.05$ & $<0.05$ \\
\hline Celeriac & 0.5 & 0.2 & $<0.05$ & $<0.05$ & $<0.05$ & $<0.05$ & $<0.05$ & $<0.05$ & $<0.05$ & $<0.05$ \\
\hline Celery stalk & 1.3 & 0.5 & $<0.05$ & $<0.05$ & $<0.05$ & $<0.05$ & $<0.05$ & $<0.05$ & $<0.05$ & $<0.05$ \\
\hline Chicory (Belgian endive) & 5.2 & 1.1 & $<0.05$ & $<0.05$ & $<0.05$ & $<0.05$ & $<0.05$ & $<0.05$ & $<0.05$ & $<0.05$ \\
\hline Corn salad & 1.2 & 0.3 & $<0.05$ & $<0.05$ & $<0.05$ & $<0.05$ & $<0.05$ & $<0.05$ & $<0.05$ & $<0.05$ \\
\hline Courgette (zucchini) & 3.5 & 1.8 & $<0.05$ & $<0.05$ & $<0.05$ & $<0.05$ & $<0.05$ & $<0.05$ & $<0.05$ & $<0.05$ \\
\hline Cucumber & 3.8 & 3.5 & $<0.05$ & $<0.05$ & $<0.05$ & $<0.05$ & $<0.05$ & $<0.05$ & $<0.05$ & $<0.05$ \\
\hline Eggplant & 0.6 & 0.3 & $<0.05$ & $<0.05$ & $<0.05$ & $<0.05$ & $<0.05$ & $<0.05$ & $<0.05$ & $<0.05$ \\
\hline Endive (US chicory) & 0.2 & $<0.05$ & $<0.05$ & $<0.05$ & $<0.05$ & $<0.05$ & $<0.05$ & $<0.05$ & $<0.05$ & $<0.05$ \\
\hline Fennel & 0.4 & 0.1 & $<0.05$ & $<0.05$ & $<0.05$ & $<0.05$ & $<0.05$ & $<0.05$ & $<0.05$ & $<0.05$ \\
\hline Garlic & $<0.05$ & $<0.05$ & $<0.05$ & $<0.05$ & $<0.05$ & $<0.05$ & $<0.05$ & $<0.05$ & $<0.05$ & $<0.05$ \\
\hline Green bean & 14.9 & 9.7 & 0.1 & 2.7 & 0.2 & 5.4 & 0.1 & 2.7 & 0.2 & 5.4 \\
\hline Leek & 2.0 & 0.6 & $<0.05$ & $<0.05$ & $<0.05$ & $<0.05$ & $<0.05$ & $<0.05$ & $<0.05$ & $<0.05$ \\
\hline Lettuce & 0.7 & 0.3 & $<0.05$ & $<0.05$ & $<0.05$ & $<0.05$ & $<0.05$ & $<0.05$ & $<0.05$ & $<0.05$ \\
\hline Mushroom & 3.5 & 1.8 & $<0.05$ & $<0.05$ & $<0.05$ & $<0.05$ & $<0.05$ & $<0.05$ & $<0.05$ & $<0.05$ \\
\hline Mushroom, canned & 0.2 & 0.1 & $<0.05$ & $<0.05$ & $<0.05$ & $<0.05$ & $<0.05$ & $<0.05$ & $<0.05$ & $<0.05$ \\
\hline Onion & 0.4 & 0.1 & $<0.05$ & $<0.05$ & $<0.05$ & $<0.05$ & $<0.05$ & $<0.05$ & $<0.05$ & $<0.05$ \\
\hline Other green salads & 8.9 & 3.0 & 0.2 & 5.4 & 0.2 & 5.4 & 0.2 & 5.4 & 0.2 & 5.4 \\
\hline
\end{tabular}




\begin{tabular}{|c|c|c|c|c|c|c|c|c|c|c|}
\hline Parsley & $<0.05$ & $<0.05$ & $<0.05$ & $<0.05$ & $<0.05$ & $<0.05$ & $<0.05$ & $<0.05$ & $<0.05$ & $<0.05$ \\
\hline Pea & 6.1 & 7.2 & $<0.05$ & $<0.05$ & $<0.05$ & $<0.05$ & $<0.05$ & $<0.05$ & $<0.05$ & $<0.05$ \\
\hline Pepper & 0.5 & 0.2 & $<0.05$ & $<0.05$ & $<0.05$ & $<0.05$ & $<0.05$ & $<0.05$ & $<0.05$ & $<0.05$ \\
\hline Radish & 2.2 & 1.1 & 0.1 & 2.7 & 0.1 & 2.7 & 0.1 & 2.7 & 0.1 & 2.7 \\
\hline Spinach & 4.1 & 3.2 & 0.1 & 2.7 & 0.2 & 5.4 & 0.1 & 2.7 & 0.2 & 5.4 \\
\hline Sorrel & 0.1 & $<0.05$ & $<0.05$ & $<0.05$ & $<0.05$ & $<0.05$ & $<0.05$ & $<0.05$ & $<0.05$ & $<0.05$ \\
\hline Swiss chard & 0.6 & 0.2 & $<0.05$ & $<0.05$ & $<0.05$ & $<0.05$ & $<0.05$ & $<0.05$ & $<0.05$ & $<0.05$ \\
\hline Tomato & 19.1 & 11.6 & $<0.05$ & $<0.05$ & $<0.05$ & $<0.05$ & $<0.05$ & $<0.05$ & $<0.05$ & $<0.05$ \\
\hline Turnip & 0.5 & 0.1 & $<0.05$ & $<0.05$ & $<0.05$ & $<0.05$ & $<0.05$ & $<0.05$ & $<0.05$ & $<0.05$ \\
\hline Watercress & $<0.05$ & $<0.05$ & $<0.05$ & $<0.05$ & $<0.05$ & $<0.05$ & $<0.05$ & $<0.05$ & $<0.05$ & $<0.05$ \\
\hline Total & 110.8 & 67.1 & 0.9 & 24.3 & 1.0 & 27.0 & 0.9 & 24.3 & 1.0 & 27.0 \\
\hline \multicolumn{11}{|l|}{ Potatoes } \\
\hline Potato & 62.5 & 59.1 & 0.2 & 5.4 & 0.4 & 10.8 & 0.2 & 5.4 & 0.4 & 10.8 \\
\hline Sweet potato & $<0.05$ & $<0.05$ & $<0.05$ & $<0.05$ & $<0.05$ & $<0.05$ & $<0.05$ & $<0.05$ & $<0.05$ & $<0.05$ \\
\hline Total & 62.6 & 59.1 & 0.2 & 5.4 & 0.4 & 10.8 & 0.2 & 5.4 & 0.4 & 10.8 \\
\hline Water & & 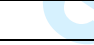 & & & & & & & & \\
\hline Mineral water & 249.8 & 196.7 & $<0.05$ & $<0.05$ & $<0.05$ & $<0.05$ & $<0.05$ & $<0.05$ & $<0.05$ & $<0.05$ \\
\hline Sparkling mineral water & 17.8 & 15.6 & $<0.05$ & $<0.05$ & $<0.05$ & $<0.05$ & $<0.05$ & $<0.05$ & $<0.05$ & $<0.05$ \\
\hline Tap water & 270.6 & 261.0 & 0.1 & 2.7 & 0.2 & 5.4 & 0.1 & 2.7 & 0.2 & 5.4 \\
\hline Water of source origin & 18.6 & 4.3 & $<0.05$ & $<0.05$ & $<0.05$ & $<0.05$ & $<0.05$ & $<0.05$ & $<0.05$ & $<0.05$ \\
\hline Coffee & 200.7 & 10.5 & 0.1 & 2.7 & $<0.05$ & $<0.05$ & 0.1 & 2.7 & $<0.05$ & $<0.05$ \\
\hline Tea & 69.3 & 8.4 & $<0.05$ & $<0.05$ & $<0.05$ & $<0.05$ & $<0.05$ & $<0.05$ & $<0.05$ & $<0.05$ \\
\hline Soup & 54.5 & 26.3 & $<0.05$ & $<0.05$ & $<0.05$ & $<0.05$ & $<0.05$ & $<0.05$ & $<0.05$ & $<0.05$ \\
\hline Total & 881.4 & 522.9 & 0.2 & 5.4 & 0.2 & 5.4 & 0.2 & 5.4 & 0.2 & 5.4 \\
\hline
\end{tabular}


Table 6: Consumption and dietary exposure of nitrite

\begin{tabular}{|c|c|c|c|c|c|c|c|c|c|c|}
\hline \multicolumn{11}{|c|}{ Food groups consumption $\left(\mathrm{g} \mathrm{day}^{-1}\right)$ and dietary exposure of nitrite $\left(\mathrm{mg} \mathrm{kg}^{-1} \mathrm{bw} \mathrm{day}^{-1}\right)$} \\
\hline \multirow[t]{2}{*}{ Food Groups } & \multirow{2}{*}{$\begin{array}{l}\text { Number of } \\
\text { consumers }\end{array}$} & \multirow{2}{*}{$\begin{array}{c}\text { Consumption } \\
\text { Mean }\end{array}$} & \multicolumn{4}{|c|}{ Lower bound estimate } & \multicolumn{4}{|c|}{ Upper bound estimate } \\
\hline & & & Mean & $\begin{array}{c}\text { Mean in \% } \\
\text { ADI }\end{array}$ & P 97.5 & $\begin{array}{c}\text { P } 97.5 \% \\
\text { ADI }\end{array}$ & Mean & $\begin{array}{c}\text { Mean in \% } \\
\text { ADI }\end{array}$ & P 97.5 & $\begin{array}{c}\text { P97.5 \% } \\
\text { ADI }\end{array}$ \\
\hline \multicolumn{11}{|l|}{ For Adults $>15$ years $(n=1474)$} \\
\hline Cheese & 475 & 3.51 & $<0.005$ & $<0.05$ & $<0.005$ & $<0.05$ & $<0.005$ & $<0.05$ & $<0.005$ & $<0.05$ \\
\hline Industrial prepared meat products * & 1450 & 99.15 & 0.01 & 16.7 & 0.04 & 66.7 & 0.02 & 33.3 & 0.04 & 66.7 \\
\hline Meat products * & 1363 & 37.11 & 0.01 & 16.7 & 0.02 & 33.3 & 0.01 & 16.7 & 0.02 & 33.3 \\
\hline Mixed dishes & 83 & 2.36 & $<0.005$ & $<0.05$ & $<0.005$ & $<0.05$ & $<0.005$ & $<0.05$ & $<0.005$ & $<0.05$ \\
\hline Offal & 104 & 1.12 & $<0.005$ & $<0.05$ & $<0.005$ & $<0.05$ & $<0.005$ & $<0.05$ & $<0.005$ & $<0.05$ \\
\hline Oil & 1 & 0.00 & $<0.005$ & $<0.05$ & $<0.005$ & $<0.05$ & $<0.005$ & $<0.05$ & $<0.005$ & $<0.05$ \\
\hline Pasta & 1132 & 35.80 & $<0.005$ & $<0.05$ & $<0.005$ & $<0.05$ & $<0.005$ & $<0.05$ & 0.01 & 16.7 \\
\hline Potatoes & 1372 & 62.52 & $<0.005$ & $<0.05$ & $<0.005$ & $<0.05$ & 0.01 & 16.7 & 0.03 & 50.0 \\
\hline Quiches & 337 & 6.00 & $<0.005$ & $<0.05$ & $<0.005$ & $<0.05$ & $<0.005$ & $<0.05$ & $<0.005$ & $<0.05$ \\
\hline Shellfish and mollusks & 160 & 0.99 & $<0.005$ & $<0.05$ & $<0.005$ & $<0.05$ & $<0.005$ & $<0.05$ & $<0.005$ & $<0.05$ \\
\hline Vegetables excluding potatoes & 1432 & 99.34 & $<0.005$ & $<0.05$ & 0.01 & 16.7 & 0.01 & 16.7 & 0.03 & 50.0 \\
\hline Water & 1389 & 556.85 & $<0.005$ & $<0.05$ & $<0.005$ & $<0.05$ & $<0.005$ & $<0.05$ & $<0.005$ & $<0.05$ \\
\hline Boiled Water & 1363 & 324.55 & $<0.005$ & $<0.05$ & $<0.005$ & $<0.05$ & $<0.005$ & $<0.05$ & $<0.005$ & $<0.05$ \\
\hline Total & & 1229.29 & 0.02 & 33.3 & 0.05 & 83.3 & 0.04 & 66.7 & 0.08 & 133.3 \\
\hline * Share of additive food-vectors & 1474 & 136.25 & 0.02 & 33.3 & 0.04 & 66.7 & 0.02 & 33.3 & 0.05 & 83.3 \\
\hline Share of non-additive food-vectors & 1474 & 1093.04 & $<0.005$ & $<0.05$ & 0.01 & 16.7 & 0.02 & 33.3 & 0.05 & 83.3 \\
\hline \multicolumn{11}{|c|}{ Children between 3 and 14 years of age $(n=1018)$} \\
\hline Cheese & 386 & 3.31 & $<0.005$ & $<0.05$ & $<0.005$ & $<0.05$ & 0.00 & $<0.05$ & $<0.005$ & $<0.05$ \\
\hline Industrial prepared meat products * & 1006 & 74.80 & 0.02 & 33.3 & 0.07 & 116.7 & 0.03 & 50.0 & 0.07 & 116.7 \\
\hline Meat products * & 932 & 27.21 & 0.01 & 16.7 & 0.03 & 50.0 & 0.01 & 16.7 & 0.03 & 50.0 \\
\hline Mixed dishes & 30 & 0.70 & $<0.005$ & $<0.05$ & $<0.005$ & $<0.05$ & 0.00 & $<0.05$ & $<0.005$ & $<0.05$ \\
\hline Offal & 44 & 0.46 & $<0.005$ & $<0.05$ & $<0.005$ & $<0.05$ & $<0.005$ & $<0.05$ & $<0.005$ & $<0.05$ \\
\hline Oil & l & l & 1 & 1 & 1 & I & / & l & l & l \\
\hline Pasta & 881 & 36.69 & $<0.005$ & $<0.05$ & $<0.005$ & $<0.05$ & 0.01 & 16.7 & 0.02 & 33.3 \\
\hline Potatoes & 988 & 59.10 & $<0.005$ & $<0.05$ & $<0.005$ & $<0.05$ & 0.02 & 33.3 & 0.06 & 100.0 \\
\hline Quiches & 206 & 3.98 & $<0.005$ & $<0.05$ & $<0.005$ & $<0.05$ & $<0.005$ & $<0.05$ & 0.01 & 16.7 \\
\hline Shellfish and mollusks & 72 & 0.59 & $<0.005$ & $<0.05$ & $<0.005$ & $<0.05$ & $<0.005$ & $<0.05$ & $<0.005$ & $<0.05$ \\
\hline Vegetables excluding potatoes & 980 & 61.90 & $<0.005$ & $<0.05$ & 0.01 & 16.7 & 0.02 & 33.3 & 0.05 & 83.3 \\
\hline Water & 990 & 477.71 & $<0.005$ & $<0.05$ & $<0.005$ & $<0.05$ & $<0.005$ & $<0.05$ & $<0.005$ & $<0.05$ \\
\hline Boiled Water & 577 & 45.23 & $<0.005$ & $<0.05$ & $<0.005$ & $<0.05$ & $<0.005$ & $<0.05$ & $<0.005$ & $<0.05$ \\
\hline
\end{tabular}




\begin{tabular}{|c|c|c|c|c|c|c|c|c|c|c|}
\hline Total & & 791.66 & 0.04 & 66.7 & 0.09 & 150.0 & 0.08 & 133.3 & 0.17 & 283.3 \\
\hline * Share of additive food-vectors & 1018 & 102.01 & 0.03 & 50.0 & 0.08 & 133.3 & 0.04 & 66.7 & 0.09 & 150.0 \\
\hline Share of non-additive food-vectors & 1018 & 689.65 & $<0.005$ & $<0.05$ & 0.01 & 16.7 & 0.05 & 83.3 & 0.10 & 166.7 \\
\hline
\end{tabular}


Table 7: Individual exposure of nitrite exceeding the ADI

\begin{tabular}{|c|c|c|c|c|}
\hline \multicolumn{5}{|l|}{ Individual exposure exceeding the ADI } \\
\hline & \multicolumn{2}{|c|}{ Low estimation } & \multicolumn{2}{|c|}{ High estimation } \\
\hline & $\begin{array}{l}\% \text { of people } \\
\text { over the ADI }\end{array}$ & {$[95 \% \mathrm{Cl}]$} & $\begin{array}{l}\text { \% of people } \\
\text { over the ADI }\end{array}$ & {$[95 \% \mathrm{Cl}]$} \\
\hline Adults $>15$ years $(n=1474)$ & 0.7 & {$[0.3 ; 1.1]$} & 16.4 & {$[14.5 ; 18.3]$} \\
\hline Children between 3 and 14 years of age $(n=1018)$ & 10.5 & {$[8.6 ; 12.4]$} & 66.2 & {$[63.3 ; 69.1]$} \\
\hline
\end{tabular}




\section{Table 8: Major food contributors to nitrite exposure}

\begin{tabular}{|c|c|c|c|c|c|c|c|c|c|c|}
\hline \multicolumn{11}{|c|}{ Food consumption $\left(\mathrm{g} \mathrm{day}^{-1}\right)$ and dietary exposure of nitrite $\left(\mathrm{mg} \mathrm{kg}^{-1}\right.$ bw day $\left.{ }^{-1}\right)$} \\
\hline & \multicolumn{2}{|c|}{ Consumption } & \multicolumn{4}{|c|}{ Lower bound estimate } & \multicolumn{4}{|c|}{ Upper bound estimation } \\
\hline & \multirow{2}{*}{$\begin{array}{c}\text { Adults }>15 \\
\text { years }\end{array}$} & \multirow{2}{*}{$\begin{array}{c}\text { Children } \\
\text { between } 3 \\
\text { and } 14 \text { years } \\
\text { of age }\end{array}$} & \multicolumn{2}{|c|}{ Adults $>15$ years } & \multicolumn{2}{|c|}{$\begin{array}{l}\text { Children between } 3 \\
\text { and } 14 \text { years of age }\end{array}$} & \multicolumn{2}{|c|}{ Adults $>15$ years } & \multicolumn{2}{|c|}{$\begin{array}{l}\text { Children between } 3 \\
\text { and } 14 \text { years of age }\end{array}$} \\
\hline & & & Mean & $\begin{array}{l}\text { Mean in \% } \\
\text { ADI }\end{array}$ & Mean & $\begin{array}{c}\text { Mean in \% } \\
\text { ADI }\end{array}$ & Mean & $\begin{array}{c}\text { Mean in \% } \\
\text { ADI }\end{array}$ & Mean & $\begin{array}{c}\text { Mean in } \\
\% \mathrm{ADI}\end{array}$ \\
\hline \multicolumn{11}{|l|}{ Meat products } \\
\hline Andouille & 0.52 & 0.12 & $<0.005$ & $<0.05$ & $<0.005$ & $<0.05$ & $<0.005$ & $<0.05$ & $<0.005$ & $<0.05$ \\
\hline Andouillette & 0.06 & 0.01 & $<0.005$ & $<0.05$ & $<0.005$ & $<0.05$ & $<0.005$ & $<0.05$ & $<0.005$ & $<0.05$ \\
\hline Bacon & 0.02 & $<0.005$ & $<0.005$ & $<0.05$ & $<0.005$ & $<0.05$ & $<0.005$ & $<0.05$ & $<0.005$ & $<0.05$ \\
\hline Bacon bits & 4.57 & 3.83 & $<0.005$ & $<0.05$ & $<0.005$ & $<0.05$ & $<0.005$ & $<0.05$ & $<0.005$ & $<0.05$ \\
\hline Black pudding (blood sausage) & 0,17 & 0.03 & $<0.005$ & $<0.005$ & $<0.005$ & $<0.05$ & $<0.005$ & $<0.05$ & $<0.005$ & $<0.05$ \\
\hline Chipolata sausage & 0.33 & 0.44 & $<0.005$ & $<0.05$ & $<0.005$ & $<0.05$ & $<0.005$ & $<0.05$ & $<0.005$ & $<0.05$ \\
\hline Chorizo dry sausage & 0.59 & 0.12 & $<0.005$ & $<0.05$ & $<0.005$ & $<0.05$ & $<0.005$ & $<0.05$ & $<0.005$ & $<0.05$ \\
\hline Cocktail sausage & 0.69 & 0.72 & $<0.005$ & $<0.05$ & $<0.005$ & $<0.05$ & $<0.005$ & $<0.05$ & $<0.005$ & $<0.05$ \\
\hline Coppa & 0.38 & 0.01 & $<0.005$ & $<0.05$ & $<0.005$ & $<0.05$ & $<0.005$ & $<0.05$ & $<0.005$ & $<0.05$ \\
\hline Dried sausage (slices) & 6.30 & 4.52 & $<0.005$ & $<0.05$ & $<0.005$ & $<0.05$ & $<0.005$ & $<0.05$ & $<0.005$ & $<0.05$ \\
\hline Dried sausage & 2.89 & 1.65 & $<0.005$ & $<0.05$ & $<0.005$ & $<0.05$ & $<0.005$ & $<0.05$ & $<0.005$ & $<0.05$ \\
\hline Foie gras, canned & 0.06 & $<0.005$ & $<0.005$ & $<0.05$ & $<0.005$ & $<0.05$ & $<0.005$ & $<0.05$ & $<0.005$ & $<0.05$ \\
\hline Frankfurter sausage & 0.07 & 0.10 & $<0.005$ & $<0.05$ & $<0.005$ & $<0.05$ & $<0.005$ & $<0.05$ & $<0.005$ & $<0.05$ \\
\hline French saveloy & 1.18 & 0.82 & $<0.005$ & $<0.05$ & $<0.005$ & $<0.05$ & $<0.005$ & $<0.05$ & $<0.005$ & $<0.05$ \\
\hline Galantine & $<0.005$ & 0.01 & $<0.005$ & $<0.05$ & $<0.005$ & $<0.05$ & $<0.005$ & $<0.05$ & $<0.005$ & $<0.05$ \\
\hline Garlic sausage & 2.45 & 1.69 & $<0.005$ & $<0.05$ & $<0.005$ & $<0.05$ & $<0.005$ & $<0.05$ & $<0.005$ & $<0.05$ \\
\hline Ham, cooked. & 4.91 & 2.97 & $<0.005$ & $<0.05$ & $<0.005$ & $<0.05$ & $<0.005$ & $<0.05$ & $<0.005$ & $<0.05$ \\
\hline Ham, raw. & 0.39 & 0.10 & $<0.005$ & $<0.05$ & $<0.005$ & $<0.05$ & $<0.005$ & $<0.05$ & $<0.005$ & $<0.05$ \\
\hline Head-cheese (Brawn) & 0.08 & $<0.005$ & $<0.005$ & $<0.05$ & $<0.005$ & $<0.05$ & $<0.005$ & $<0.05$ & $<0.005$ & $<0.05$ \\
\hline Merguez sausage & 2.08 & 0.95 & $<0.005$ & $<0.05$ & $<0.005$ & $<0.05$ & $<0.005$ & $<0.05$ & $<0.005$ & $<0.05$ \\
\hline Montbeliard sausage & 0.09 & $<0.005$ & $<0.005$ & $<0.05$ & $<0.005$ & $<0.05$ & $<0.005$ & $<0.05$ & $<0.005$ & $<0.05$ \\
\hline Mortadella & 0.29 & 0.26 & $<0.005$ & $<0.05$ & $<0.005$ & $<0.05$ & $<0.005$ & $<0.05$ & $<0.005$ & $<0.05$ \\
\hline Morteaux sausage & 0.22 & 0.21 & $<0.005$ & $<0.05$ & $<0.005$ & $<0.05$ & $<0.005$ & $<0.05$ & $<0.005$ & $<0.05$ \\
\hline Others meat products & 0.94 & 0.42 & $<0.005$ & $<0.05$ & $<0.005$ & $<0.05$ & $<0.005$ & $<0.05$ & $<0.005$ & $<0.05$ \\
\hline Pâté & 0.09 & 0.09 & $<0.005$ & $<0.05$ & $<0.005$ & $<0.05$ & $<0.005$ & $<0.05$ & $<0.005$ & $<0.05$ \\
\hline Pâté, duck & 0.01 & $<0.005$ & $<0.005$ & $<0.05$ & $<0.005$ & $<0.05$ & $<0.005$ & $<0.05$ & $<0.005$ & $<0.05$ \\
\hline Pâté, fish and sellfish & 0.09 & 0.02 & $<0.005$ & $<0.05$ & $<0.005$ & $<0.05$ & $<0.005$ & $<0.05$ & $<0.005$ & $<0.05$ \\
\hline
\end{tabular}




\begin{tabular}{|c|c|c|c|c|c|c|c|c|c|c|}
\hline Pâté in pastry. & 0.10 & 0.01 & $<0.005$ & $<0.05$ & $<0.005$ & $<0.05$ & $<0.005$ & $<0.05$ & $<0.005$ & $<0.05$ \\
\hline Pâté, poultry liver & 0.02 & $<0.005$ & $<0.005$ & $<0.05$ & $<0.005$ & $<0.05$ & $<0.005$ & $<0.05$ & $<0.005$ & $<0.05$ \\
\hline Pâté, pork liver & 0.02 & $<0.005$ & $<0.005$ & $<0.05$ & $<0.005$ & $<0.05$ & $<0.005$ & $<0.05$ & $<0.005$ & $<0.05$ \\
\hline Pigeon, roasted & 0.39 & 0.03 & $<0.005$ & $<0.05$ & $<0.005$ & $<0.05$ & $<0.005$ & $<0.05$ & $<0.005$ & $<0.05$ \\
\hline Rillettes & 0.03 & 0.01 & $<0.005$ & $<0.05$ & $<0.005$ & $<0.05$ & $<0.005$ & $<0.05$ & $<0.005$ & $<0.05$ \\
\hline Roasted pheasant & 1.06 & 0.39 & $<0.005$ & $<0.05$ & $<0.005$ & $<0.05$ & $<0.005$ & $<0.05$ & $<0.005$ & $<0.05$ \\
\hline Rosette dry sausage & 0.10 & 0.27 & $<0.005$ & $<0.05$ & $<0.005$ & $<0.05$ & $<0.005$ & $<0.05$ & $<0.005$ & $<0.05$ \\
\hline Salami & 1.71 & 1.58 & $<0.005$ & $<0.05$ & $<0.005$ & $<0.05$ & $<0.005$ & $<0.05$ & $<0.005$ & $<0.05$ \\
\hline Sausage meat & 0.03 & $<0.005$ & $<0.005$ & $<0.05$ & $<0.005$ & $<0.05$ & $<0.005$ & $<0.05$ & $<0.005$ & $<0.05$ \\
\hline Snack & 0.02 & 0.06 & $<0.005$ & $<0.05$ & $<0.005$ & $<0.05$ & $<0.005$ & $<0.05$ & $<0.005$ & $<0.05$ \\
\hline Strasbourg sausage & 2.54 & 3.11 & $<0.005$ & $<0.05$ & $<0.005$ & $<0.05$ & $<0.005$ & $<0.05$ & $<0.005$ & $<0.05$ \\
\hline Toulouse sausage & 2.89 & 3.08 & $<0.005$ & $<0.05$ & $<0.005$ & $<0.05$ & $<0.005$ & $<0.05$ & $<0.005$ & $<0.05$ \\
\hline Tripes à la mode de Caen & 0.16 & $<0.005$ & $<0.005$ & $<0.05$ & $<0.005$ & $<0.05$ & $<0.005$ & $<0.05$ & $<0.005$ & $<0.05$ \\
\hline Vegetable terrines and mousses & 0,04 & $<0.005$ & $<0.005$ & $<0.05$ & $<0.005$ & $<0.05$ & $<0.005$ & $<0.05$ & $<0.005$ & $<0.05$ \\
\hline White pudding (white sausage) & 0,00 & 0.01 & $<0.005$ & $<0.05$ & $<0.005$ & $<0.05$ & $<0.005$ & $<0.05$ & $<0.005$ & $<0.05$ \\
\hline Total & 37.11 & 27.21 & 0.01 & 16.7 & 0.01 & 16.7 & 0.01 & 16.7 & 0.01 & 16.7 \\
\hline \multicolumn{11}{|l|}{ Industrial prepared meat products } \\
\hline Processed beef & 31.50 & 29.31 & $<0.005$ & $<0.05$ & 0.01 & 16.7 & $<0.005$ & $<0.05$ & 0.01 & 16.7 \\
\hline Processed boar & 0.07 & 0.03 & $<0.005$ & $<0.05$ & $<0.005$ & $<0.05$ & $<0.005$ & $<0.05$ & $<0.005$ & $<0.05$ \\
\hline Processed chicken & 22.42 & 15.52 & 0.01 & 16.7 & 0.01 & 16.7 & 0.01 & 16.7 & 0.01 & 16.7 \\
\hline Processed duck & 2.35 & 1.51 & $<0.005$ & $<0.05$ & $<0.005$ & $<0.05$ & $<0.005$ & $<0.05$ & $<0.005$ & $<0.05$ \\
\hline Processed hare & 0.20 & 0.03 & $<0.005$ & $<0.05$ & $<0.005$ & $<0.05$ & $<0.005$ & $<0.05$ & $<0.005$ & $<0.05$ \\
\hline Processed lamb & 5.28 & 2.84 & $<0.005$ & $<0.05$ & $<0.005$ & $<0.05$ & $<0.005$ & $<0.05$ & $<0.005$ & $<0.05$ \\
\hline Processed pork & 16.82 & 10.28 & $<0.005$ & $<0.05$ & $<0.005$ & $<0.05$ & $<0.005$ & $<0.05$ & $<0.005$ & $<0.05$ \\
\hline Processed quail & 0.27 & 0.25 & $<0.005$ & $<0.05$ & $<0.005$ & $<0.05$ & $<0.005$ & $<0.05$ & $<0.005$ & $<0.05$ \\
\hline Processed rabbit & 4.67 & 2.24 & $<0.005$ & $<0.05$ & $<0.005$ & $<0.05$ & $<0.005$ & $<0.05$ & $<0.005$ & $<0.05$ \\
\hline Processed turkey & 5.98 & 5.89 & $<0.005$ & $<0.05$ & $<0.005$ & $<0.05$ & $<0.005$ & $<0.05$ & $<0.005$ & $<0.05$ \\
\hline Processed veal & 5.23 & 3.69 & $<0.005$ & $<0.05$ & $<0.005$ & $<0.05$ & $<0.005$ & $<0.05$ & $<0.005$ & $<0.05$ \\
\hline Other processed game & 0.14 & $<0.005$ & $<0.005$ & $<0.05$ & $<0.005$ & $<0.05$ & $<0.005$ & $<0.05$ & $<0.005$ & $<0.05$ \\
\hline Other processed meat products & 2,79 & 2.79 & $<0.005$ & $<0.05$ & $<0.005$ & $<0.05$ & $<0.005$ & $<0.05$ & $<0.005$ & $<0.05$ \\
\hline Total & 99.15 & 74.80 & 0.01 & 16.7 & 0.02 & 33.3 & 0.02 & 33.3 & 0.03 & 50.0 \\
\hline
\end{tabular}

